\title{
Türk Yükseköğreniminin Görünümü: Betimsel Bir Analiz
}

\author{
Metin Toprak ${ }^{1 *}$, Deniz Kolat ${ }^{2}$, Mehmet Şengül ${ }^{3}$, Armağan Erdoğan ${ }^{4}$ \\ IIstanbul Üniversitesi \\ 2Batman Üniversitesi, thanisss@gmail.com \\ ${ }^{3}$ Mustafa Kemal Üniversitesi, msmehmetsengul@gmail.com \\ ${ }^{4}$ Ankara Sosyal Bilimler Üniversitesi, armagan.erdogan@asbu.edu.tr \\ ORCID: M. Toprak (0000-0001-9217-6318), M. Şengül (0000-0002-6661-2953)
}

\begin{abstract}
Özet
Türk yükseköğrenim sisteminin nicel göstergeler itibariyle temel özellikleri; eğitim program çeşidi, eğitim program sayısı ve programlar itibariyle öğrenci ve öğretim elemanı sayıları, ekonomik sektörlerin ihtiyaç duyduğu insan kaynağı bakımından hayati önemdedir. Yine, beş yıllık kalkınma planlarında ekonomik sektörler bazında nicel ve nitel insan kaynağı öngörüsü bakımından yükseköğrenim sisteminin röntgeninin çekilmesi kritik önemdedir. Bu çalıșmada, uluslararası standart eğitim sınıflaması (ISCED) çerçevesinde, Türk yükseköğrenim sistemi nicel verilere dayalı olarak ele alınmaktadır. Böylece, Türk yükseköğrenim sisteminin, temel özellikleri itibariyle uluslararası karşlaş̦tırmalara imkân vermesi sağlanacaktır.

Sonuç olarak, eğitim sınıflaması (ISCED), meslek ve uğraşı sınıflaması (ISCO) ve ekonomik faaliyet sınıflaması (ISIC) arasında kurulacak bağlantılara dayalı insan kaynakları planlaması hem ulusal politikalar bakımından hem de uluslararası raporlama ve karșılaştırmalar bakımından yararlı olacaktır.
\end{abstract}

Anahtar Kelimeler: ISCED sınıflaması, Türk yükseköğrenim sistemi, Türk üniversite sistemi, Avrupa yükseköğrenim alanı, yükseköğrenim politikası.

\section{Appearance of Turkish Higher Education: A Descriptive Analysis}

\begin{abstract}
Basic features of Turkish higher education system in terms of quantitative indicators are vital for the human resources needed by economic sectors. The type and number of education program and the numbers of students and teaching staff are primary quantitative indicators. In addition, it is critical to make an $\mathrm{x}$-ray of the higher education system in terms of quantitative and qualitative human resource projection based on economic sectors in the five-year development plans. In this study, Turkish higher education system is handled based on quantitative data within the framework of international standard classification of education (ISCED). Thus, it will be ensured that Turkish higher education system will enable international comparisons in terms of its basic features.

Consequently, human resource planning based on the links between education classification (ISCED), occupational classification (ISCO) and economic activity classification (ISIC) would be useful both in terms of national policies and international reporting and comparisons; and starting point is classification of education in the higher education system.
\end{abstract}

Key Words: ISCED classification, Turkish higher education system, Turkish university system, European higher education area, higher education policy.

\section{Gíriş}

Ülkemizin Bologna sürecine dahil olmasıyla birlikte Türk Yükseköğrenim sistemi ile Avrupa Yükseköğrenim sistemlerinin karşılaştırılmasına olanak sağlayacak olan yükseköğretimde ulusal yeterlilikler çerçevesi oluștu-

*Yazışma Adresi / Address for Correspondence: Metin Toprak, Email: metin.toprak@istanbul.edu.tr

Geliş Tarihi / Received Date: 04.08.2019

Kabul Tarihi / Accepted Date: 21.08.2019

Doi: $10.26701 /$ uad. 601362 rulmasına yönelik çalışmalar 2005 yilında Bergen'1'de gerçekleştirilen Bologna Bakanlar Zirvesi sonrasında başlatılmış, süreç içerisinde Türkiye Yeterlilikler Çerçevesine yönelik çalışmalar (TYÇ) Yükseköğretim Kurulu Başkanlığı (YÖK), Milli Eğitim Bakanlığı (MEB) ve Mesleki Yeterlilik Kurumu (MYK) işbirliği ile yürütülmüş ve 2016 yllının Ocak ${ }^{2}$ ayında yürürlüğe girmiştir. Türk

\footnotetext{
${ }^{1}$ Detaylı bilgi için bakınız: https://uluslararasi.yok.gov.tr/uluslararasilasma/bologna/temel-bildirgeler-ve-geli\%C5\%9Fmeler/bergen-bildirgesi, http://www.ehea. info/cid101762/ministerial-conference-bergen-2005.html

${ }^{2}$ 02.01.2016 tarih ve 29581 sayılı resmi gazete ile yürürlüğe girmiştir. Detaylı bilgi için bakınız: https://www.myk.gov.tr/index.php/tr/tuerkiye-yeterlilikler-cercevesi,
} 
yükseköğrenim sistemi ile Avrupa Yükseköğrenim Alanı karşılaştırılarak referanslanmış ve 29 Mart 2017 tarihinde Brüksel'de iki sistem arasındaki paralellik teyit edilmiştir (MYK, 2016). Yükseköğrenim sisteminin seviye ve derece olarak tasarımı; çıktıya ve sürece yönelik kalite güvence sistemi; düzenleyici otoritelerle icracı mercilerin ayrılı̆̆ı; diploma ve sertifikaya dayalı öğrenmelerle serbest öğrenmelere yönelik düzenlenme ve tanıma prosedürleri ile sürece sosyal paydaşların aktif katılımı konusunda Türk üniversite sisteminin organizasyonel ve işlevsel tasarımı ve işletim performansı, Avrupa'nın yükseköğrenim alanı için geliştirdiği çerçeveler ile büyük ölçüde uyum içindedir.

Türk yükseköğreniminde, önlisanstan doktora düzeyine kadar eğitim programları, öğrenci sayıları ve öğretim elemanları istatistikleri hazırlanırken; ulusal düzeyde işlev odaklı, organizasyonel yapılanma odaklı sınıflamalar öne çıkarken, uluslararası düzeyde sınıflamada ise istatistiki raporlama amaçlı sınıflama öne çıkmaktadır.

Birleşmiş Milletler Eğitim, Bilim ve Kültür Örgütü (UNESCO) dünyada kullanılan uluslararası standart eğitim sınıflamasını (ISCED) belirli periyotlarda güncellemektedir. İlk olarak 1976 yılında geliştirilen ve daha sonra 1997 ve 2011 yıllarında güncellenen eğitim sınıflaması 2013 yılı revizyonu olarak son halini almış ve 2015 yılında yayımlanmıştır (UNESCO, 2015). Türkiye'de TÜIK, YÖK, ÖSYM, MEB, IŞKUR ve MYK gibi kurumlar uluslararası raporlamalarda UNESCO ve diğer Birleşmiş Milletler örgütleri tarafından geliştirilen çerçeveleri kullanmaktadır. YÖK, 2011 yılında "sektörel yeterlilikler çerçevesi"ni oluşturmak üzere başlattığı, ancak "alan yeterlilikleri” olarak isimlendirdiği bir çerçeve yayımlamış ve yükseköğretim kurumlarını uygulamakla yükümlü kılmıştır. ISCED sınıflamasındaki geniş, dar, ayrıntılı alanlar ile program ve konu kırılımını esas alarak geliştirilen "alan yeterlilikleri çerçevesi” çalışması daha tutarlı bir çerçeve olup, bunun sektörel çerçeveyi ikame etmediği ifade edilmektedir (Stonkiene, Matkeviciene ve Vaiginiene, 206; Toprak, Erdoğan ve Açıkgöz, 2013).

Bir ülkede, insan kaynağının bilgi, beceri ve yetkinlik kazanmasında ana mecra, liselerde ve üniversitelerde verilen diplomaya dayalı eğitimdir. Yine $M E B$ ve üniversite onaylı sertifika programları ile yetkilendirilmiş çeşitli kamu ve özel kuruluşlarca verilen sertifika programları da pratikte hayli yaygındır. İş başında veya yaparak öğrenmeye yönelik tanıma, henüz gelişme evresinde olduğu için, Türkiye'de bu mecradan gelen yetkinliklerin henüz envanteri çıkarılmamış ve hangi yeterliliklere karşılık geldiği tespit edilememiştir (Wu ve Shen, 2016; Spöttl, 2013; Niu, Jiang ve Li, 2010; Chhokar, 2010; Markowitsch ve Plaimauer, 2009).

Türkiye kurumlarının uluslararası kurumlara yaptıkları raporlamalar, oldukça genel olup alt kırılımlara yer vermemektedir. Bu çalışmada, YÖK veri tabanındaki eğitim

https://myk.gov.tr/images/articles/editor/130116/TYC_teblig_2.pdf programları çeşit, sayı ve düzey bakımından; öğrenci sayısı program çeşidi ve program sayısı bakımından ve nihayet akademik personel sayısı program çeşidi ve program sayısı bakımından analiz edilmekte, Türk yükseköğrenim sektörü, program, öğrenci ve akademisyen boyutlarıyla betimsel bir analize tabi tutulmaktadır.

Literatürde bugüne kadar, ISCED sınıflamasını esas alarak yukarıdaki çerçevede bir çalışma yapılmamıştır (Soysal ve diğ., 2019; Gür, Çelik ve Yurdakul, 2018). MEB ve YÖK, MYK, İSKKUR ve TÜİK gibi ulusal düzeyde karar alıcıların, yükseköğretim kurumlarının ve meslek odaları ile sendikaların bu çalışmadan eğitim sisteminin güçlü ve zayıf yönleri ile geliştirilmeye açı yönlerinin analizine imkân veriyor olması sebebiyle yararlanabilecekleri değerlendirilmektedir. Türk yükseköğrenimini yapısal olarak ortaya koyar nitelikteki bu çalışma hâlihazırda politika üreticileri için veri niteliğindedir.

\subsection{YÖK temel alanları ve ISCED sınıflaması}

YÖK ve ÜAK yükseköğrenim program sınıflamaları aynıdır. YÖK, yükseköğretim kurumlarındaki programları 12 temel alan itibariyle kategorize etmektedir. Bu sınıflamada, programların ait olduğu yüksek okul, fakülte ve enstitü etkili olduğu gibi, Türkiye'nin yükseköğrenim geleneğinden gelen sınıflama tecrübesi de etkilidir. Dolayısıyla, ulusal geleneğin belirleyici olduğu işlevsel ve organizasyonel bazlı sınıflamanın (Gülmez ve Yavuz 2019) geçerli olduğu söylenebilir.

ISCED sınıflaması, uluslararası karşılaştırılabilir eğitim istatistiklerinin toplulaştırılması, derlenmesi ve analiz edilmesi için kullanılan bir çerçeve olup, oldukça genel bir çerçeveye dayanmaktadır. ISCED ve YÖK sınıflamaları önemli ölçüde paralellik göstermektedir. YÖK’ün belirlediği 12 temel alan, ISCED'deki 10 geniş alana karşıllı gelmektedir. YÖK ve ISCED alanları arasında aşağıdaki farklılıkların olduğu söylenebilir:

ISCED'de genel programlar ve yeterlilikler geniş alanında öngörülen programlar, YÖK temel alan sınıflamasında ağırlıklı olarak eğitim bilimleri ve öğretmen yetiştirme temel alanı içinde yer almaktadır. ISCED eğitim geniş alanı içinde yer alan programlar da YÖK sınıflamasında, eğitim bilimleri ve öğretmen yetiştirme temel alanı içindedir. Eğitim fakültelerinde alan uzmanlığı olan programlar ilgili fakültelere kaydırıldığı için, daha önceki yıllarda eğitim temel alanı içinde bulunan alan öğretmenlikleri artık fen bilimleri ve matematik, sosyal, beşerî ve idari bilimler veya ilahiyat, filoloji gibi temel alanlarında yer almaktadır.

ISCED'de sanat ve beşerî bilimler; sosyal bilimler, gazetecilik ve enformasyon; işletme, yönetim ve hukuk ile hizmetler geniş alanlarındaki programlar, YÖK sınıflamasında farklı bir tasnife sahiptir. YÖK sınıflamasında sosyal, beşerî ve idari bilimler; ilahiyat; filoloji ve güzel sanatlar ayrı temel alanlar olarak tasarlanmıştır. Bu durumda, YÖK tasnifinde ilahiyat ve filoloji programlarının beşerî bilimler dışında tutulduğu söylenebilir. 
ISCED'de ișletme, yönetim ve hukuk programları aynı geniş alanda yer alırken, YÖK tasnifinde hukuk ayrı bir temel alan olarak düşünülmekte ve yönetim ve işletme sosyal bilimler altında yer almaktadır. ÖSYM tarafından yapılan üniversite giriş sınavlarında hesaplanan puan türleri, eğitim programlarının sayısal ve sözel nitelikleri, doçentlik sınavlarındaki alan sınıflamaları gibi ulusal ölçekte anlamlı olan çerçevelerin YÖK temel alan tasarımında etkili olduğu söylenebilir. Güzel sanatlar, YÖK tasnifinde ayrı bir temel alan olduğu halde, ISCED'de beșerî bilimlerle aynı geniş alan içinde yer almaktadır. YÖK ve ISCED sınıflamasında doğa bilimleri, matematik ve istatistik paralel bir şekilde tasarlanmış ve aynı alan içinde gruplandırılmıştır.

ISCED'de mühendislik, imalat ve inşaat aynı geniş alanda iken, YÖK'te mimarlık, planlama ve tasarım ile mühendislik ayrı iki temel alanda değerlendirilmiştir. Yine bilgi ve iletişim teknolojileri ISCED'de ayrı bir geniş alanda dikkate alınırken, YÖK'te mühendislik temel alanı içinde düşünülmüștür. ISCED'de refah başlığı altında toplanan programlar sağlık programları ile birlikte aynı geniş alanda gruplandırılırken, YÖK'te refah programları daha ziyade sosyal, beșerî ve idari bilimler temel alanı altında tasnif edilmiştir. Spor alanı ile ilgili programlar ISCED'de refah programları ile birlikte dikkate alınırken, YÖK'te spor bilimleri temel alanı altında gruplandırılmıștır. Veterinerlik programları, ISCED'de ziraat, ormancllık, balıkçlık ve veterinerlik geniş alanı içinde yer alırken, YÖK tasnifinde sağlık programları altında gruplandırılmıştır (Tablo 1.1).

Bir programın hangi geniş, dar veya ayrıntılı alanda sınıflandırılacağını belirleyen husus, "ana konudur". ISCED ve YÖK sinıflamaları arasındaki farklılıklarda, eğitim programı ve bunlardan mezun olanların mesleklerine yönelik düzenlemeler, bu programların üniversitede yer aldıkları akademik birimler ve bu programların yapılandırılmışlık düzeyleri belirleyici olmaktadır. ISCED, geniş alandaki programları, ikinci seviyede dar alan, üçüncü seviyede ise ayrintılı alan sinıflamasına tabi tutarak ulusal düzeyde kullanıma da imkân vermektedir. Bu bakımdan Türkiye'deki programların ISCED sınıflaması çerçevesinde yeniden sınıflandırılmasının daha uygun olacağı değerlendirilmektedir. Çünkü, mevcut YÖK sınıflaması, sadece temel alan itibariyle bir sınıflama olup (ISCED'deki geniş alan sınıflamasına karşılık gelmektedir), ulusal düzeydeki farklı karar alıcı kurumlara ISCED'in sunduğu kadar bilgi ve bulgu sunmamaktadır.

Tablo 1.1. YÖK ve ISCED eğitim programları sınıflamaları

\begin{tabular}{|l|l|}
\hline \multicolumn{1}{|c|}{ YÖK / ÜAK Temel Alanları } & \multicolumn{1}{c|}{ ISCED Geniş Alanları } \\
\hline $\begin{array}{l}\text { Eğitim Bilimleri ve Öğretmen Yetiştir- } \\
\text { me Temel Alanı }\end{array}$ & $\begin{array}{l}00 \text { Genel programlar ve yeterli- } \\
\text { likler }\end{array}$ \\
\hline 01 Eğitim \\
\hline $\begin{array}{l}\text { Sosyal-Beşerî ve İdari Bilimler Temel } \\
\text { Alanı }\end{array}$ & 02 Sanat ve beşerî bilimler \\
\hline İlahiyat Temel Alanı & $\begin{array}{l}03 \text { Sosyal bilimler, gazetecilik ve } \\
\text { enformasyon }\end{array}$ \\
\hline
\end{tabular}

\begin{tabular}{|l|l|}
\hline \multicolumn{1}{|c|}{ YÖK / ÜAK Temel Alanları } & \multicolumn{1}{c|}{ ISCED Geniş Alanları } \\
\hline Filoloji Temel Alanı & 04 Isşletme, yönetim ve hukuk \\
\hline Güzel Sanatlar Temel Alanı & 10 Hizmetler \\
\hline Hukuk Temel Alanı & \\
\hline & 05 Doğa bilimleri, matematik ve \\
\hline Fen Bilimleri ve Matematik Temel Alanı & istatistik \\
\hline & 07 Mühendislik, imalat ve inşaat \\
\hline Mimarlık-Planlama-Tasarım & 06 Bilgi ve Illetişim Teknolojileri \\
\hline Mühendislik Temel Alanı & 09 Sağlık ve refah \\
\hline \begin{tabular}{l} 
Sağlık Bilimleri Temel Alanı \\
\hline Spor Bilimleri Temel Alanı
\end{tabular} & \\
\hline $\begin{array}{l}\text { Ziraat ve Orman ve Su Ürünleri Temel } \\
\text { Alanı }\end{array}$ & $\begin{array}{l}\text { 08 Ziraat, ormancılık, balıkçlık ve } \\
\text { veterinerlik }\end{array}$ \\
\hline $\begin{array}{l}\text { Kaynak: YÖK ve ÜAK temel alan sınıflamaları ile ISCED geniş alan sınıfla- } \\
\text { ması. } \\
\text { YOK için; https://akademik.yok.gov.tr/AkademikArama/, } \\
\text { ÜAK için; http://www.uak.gov.tr/?q=node/92, } \\
\text { ISCED için; http://uis.unesco.org/sites/default/files/documents/interna- } \\
\text { tional-standard-classification-of-education-fields-of-education-and-trai- } \\
\text { ning-2013-detailed-field-descriptions-2015-en.pdf }\end{array}$ \\
\hline
\end{tabular}

\section{TÜRK YÜKSEKÖĞRENIMININ NICELIKSEL GÖRÜNÜMÜ}

Bu bölümde, Türk yükseköğrenimi öğrenci ve akademik personel sayısı, örgün ve açı öğretim sistemleri, devlet ve vakıf üniversiteleri, önlisanstan doktoraya kadar öğrenim düzeyleri itibariyle değerlendirilecektir. ${ }^{3}$

\subsection{Yükseköğrenim kurumu sayısı}

Türkiye, AK Parti iktidarı döneminde yükseköğrenimde devasa bir genişlemeye gitti (Günay ve Günay, 2011). Dünyada da 21'inci yüzyıl, birçok ülkede yükseköğrenimde kitlesel genişlemeye şahit olmuştur (Li ve Lin, 2015; Siemienska ve Walczak, 2012; Ngok, 2008). 2003 yılında 53'ü devlet, 22'si vakıf olmak üzere toplam 75 üniversite vardı. Açık öğretim dahil toplam öğrenci sayısı 1.882.630 olup, bunun \%96,7'si devlet üniversitelerinde eğitim görmekteydi. Bu tarihte örgün ve açık öğretim verileri ayrıştırılarak verilmediği için, bu yönde bir analiz yapılamamıştır. 31 Mart 2019 itibariyle 129 devlet üniversitesi, 72 vakıf üniversitesi ve 5 bağımsız meslek yüksek okulu mevcuttur (Tablo 2.1).

Tablo 2.1. Yükseköğrenim kurumları (Mayıs 2019)

\begin{tabular}{|c|c|c|c|c|}
\hline Statüsü & $\mathbf{2 0 0 3}$ Sayı & Yüzde & $\mathbf{2 0 1 9}$ Sayı & Yüzde \\
\hline Devlet üniversitesi & 53 & 70,7 & 129 & 62,6 \\
\hline Meslek Yüksekokulu & - & - & 5 & 2,4 \\
\hline Vakıf üniversitesi & 22 & 29,3 & 72 & 35,0 \\
\hline Toplam & 75 & 100,0 & 206 & 100,0 \\
\hline
\end{tabular}

Kaynak: YÖK Istatistik Veri Tabanı, https://istatistik.yok.gov.tr/

\footnotetext{
${ }^{3}$ Yükseköğretim sözcüğü, bu hizmeti sunan kurum ve eğitici yönünden tanımlandığı için ettirgen nitelikte olup, öğreteni ve sunanı merkeze almaktadır. Oysa günümüzde gelişmiş ülkelerdeki yaklaşıma paralel olarak, öğreneni merkeze almak gerektiği için sözcüğün "yükseköğrenim" olarak kullanılması daha uygun olacaktır. Bu durum, içinde "öğretim" ibaresi geçen diğer sözcükler için de geçerlidir; örneğin, öğretme yerine öğrenme, öğretim yerine öğrenim gibi. Ancak Türkçe kullanımda yükseköğretim resmi ve günlük hayatta yaygın kullanıldığı için bu çalışmada bu şekilde kullanılmasında bir sakınca görülmemekle birlikte, resmi kullanımlar dışında yükseköğrenim sözcüğü daha çok tercih edilmiştir.
} 


\section{2 Öğrenim türü itibariyle program çeşidi, program sayısı ve öğrenci sayısı}

Yükseköğrenim kurumlarında önlisanstan doktoraya kadar toplam 5.540 çeşit program bulunmaktadır. Program çeşitliliği, farklı öğrenim düzeylerinde ve farklı isimlerdeki ve kodlardaki programları kapsamaktadır. Dolayısıyla, bir program aynı isimle önlisanstan doktoraya kadar dört çeşit program olarak dikkate alınmaktadır. Yükseköğrenimdeki program sayısı ise 45.145 adettir. Bir program çeşidinde yükseköğrenim kurumlarının sayısına bağlı olarak birden fazla program açıldığı için, program sayısı program çeşidinin ortalama 8,1 katı kadardır (Tablo 2.2 ve Tablo 2.3 ).

Toplam sayısı 45.145 olan programların bir kısmında (1.548) kayıtlı öğrenci bulunmamaktadır. Öğrencisi olmayan program sayısı \%3,4'tür. Toplam programlar içinde öğrencisi bulunmayan program oranı sanatta yeterlikte $\% 13$, yüksek lisansta $\% 6$, doktorada $\% 3,5$, önlisansta $\% 3$ ve lisansta \%1 civarındadır. Öğrenim düzeyleri itibariyle dağılımda, öğrencisi bulunmayan programların \%54'ü yüksek lisans programları olup; bunu, \%22 ile önlisans, \%13 ile doktora ve \%10 ile lisans programları izlemektedir (Tablo 2.2).

Yükseköğrenim programları çeşit bakımından incelendiğinde, program çeşidi içinde birinci öğretim (gündüz) programları \%78,2 (4.332 adet), ikinci öğretim \%16,6 (919 adet), uzaktan öğretim programları \%3,8 (211 adet) ve açı ögrretim programları \%1,4 (78 adet) paya sahiptir. Öğrenim türü başına düşen program sayısı, birinci öğretimde artmakta, diğer öğretim türlerinde ise azalmakta- dir (Tablo 2.3).

Birinci öğretimdeki programlarda, program sayısı program çeşidinin 9,1 katı iken, ikinci öğretimde 5,4 katı, uzaktan öğretimde 2,5 katı ve açık öğretimde 2 katıdır. Normal yüz yüze eğitimin dışındaki eğitim türlerinde (açı ve uzaktan) görece az sayıdaki programda kitlesel olarak fazla öğrenci kayıtlı durumdadır. Nitekim normal öğretimde (birinci ve ikinci öğretim birlikte) program başına düşen öğrenci sayısı 84,9 iken, birinci öğretimde 78,1, ikinci öğretimde 139,7, uzaktan öğretimde 158,3 ve açı öğretimde 25.038'dir. Açı öğretim programlarında kayıtlı öğrenciler hariç tutulduğunda, program başına düşen öğrenci sayısı ortalama 85’tir (Tablo 2.3).

\subsection{Yükseköğrenimde devlet üniversitelerinin ağırlığı}

2018-19 eğitim yılında, açık öğretime kayıtlı olanlar hariç öğrencilerin \%84,3’ü devlet üniversitelerinde eğitim görmektedir. Açık öğretim öğrencilerinin tamamı devlet üniversitelerine kayıtlıdır. Örgün eğitim (birinci ve ikinci öğretim) öğrencilerinin \%82,4’ü devlet üniversitelerine kayıtlıyken, açık öğretim öğrencilerinin tamamı ve uzaktan öğretim öğrencilerinin ise yüzde 88,5'i devlet üniversitelerine kayıtlıdır. Görece çok düşük olan Vakıf MYO’larına kayıtlı öğrenci sayıları, Vakıf üniversiteleri içinde değerlendirilebilecek düzeyde düşük bir orandadır (Tablo 2.4).

Türk yükseköğreniminde (açık öğretim hariç), kayıtlı öğrenci sayısı bakımından vakıf yükseköğrenim kurumlarının payı \%16’ya yaklaşmaktadır. Tezsiz yüksek lisans programlarının gelir getirici olması ve bu programlara

Tablo 2.2. Öğrenim düzeyleri itibariyle öğrencisi bulunmayan programlar (Mayıs 2019)

\begin{tabular}{|c|c|c|c|c|c|c|}
\hline Öğrenim düzeyi & $\begin{array}{l}\text { Öğrencisi olmayan } \\
\text { program çeşidi } \\
\text { (A) }\end{array}$ & $\begin{array}{c}\text { Toplam program } \\
\text { çeşidi } \\
\text { (B) }\end{array}$ & $\begin{array}{l}\text { Öğrencisi olmayan } \\
\text { program sayısı } \\
\text { (C) }\end{array}$ & $\begin{array}{l}\text { Toplam prog- } \\
\text { ram sayısı } \\
\text { (D) }\end{array}$ & $\begin{array}{l}\text { Öğrencisi olmayan } \\
\text { program oranı, \% } \\
\text { (C)/(D) }\end{array}$ & $\begin{array}{c}\text { Öğrencisi olmayan } \\
\text { programların (C) } \\
\text { dağılımı, \% }\end{array}$ \\
\hline Önlisans & 179 & 600 & 341 & 13.189 & 2,6 & 22,0 \\
\hline Lisans & 81 & 733 & 148 & 12.231 & 1,2 & 9,6 \\
\hline Sanatta yeterlik & 16 & 63 & 18 & 138 & 13,0 & 1,2 \\
\hline Yüksek lisans & 660 & 2.907 & 836 & 13.714 & 6,1 & 54,0 \\
\hline Doktora & 180 & 1.237 & 205 & 5.873 & 3,5 & 13,2 \\
\hline Toplam & 1.116 & 5.540 & 1.548 & 45.145 & 3,4 & 100,0 \\
\hline
\end{tabular}

Kaynak: YÖKSis Veri Tabanı.

Tablo 2.3. Öğrenim türü itibariyle program çeşidi, program sayısı ve öğrenci sayısı (Mayıs 2019)

\begin{tabular}{|c|c|c|c|c|c|c|c|c|}
\hline & $\begin{array}{c}\text { Program } \\
\text { çeşidi }\end{array}$ & \% dağılım & $\begin{array}{c}\text { Program } \\
\text { sayısı }\end{array}$ & \% dağılım & $\begin{array}{c}\text { Öğrenci } \\
\text { sayısı }\end{array}$ & \% dağılımı & $\begin{array}{c}\text { Program sayısı / } \\
\text { Program çeşidi }\end{array}$ & $\begin{array}{c}\text { Öğrenci sayısı / } \\
\text { program sayısı }\end{array}$ \\
\hline Birinci Öğretim & 4.332 & 78,2 & 39.546 & 87,6 & 3.089 .285 & 39,9 & 9,1 & 78,1 \\
\hline İkinci Öğretim & 919 & 16,6 & 4.923 & 10,9 & 687.829 & 8,9 & 5,4 & 139,7 \\
\hline Uzaktan Öğretim & 211 & 3,8 & 521 & 1,2 & 82.457 & 1,1 & 2,5 & 158,3 \\
\hline Açık Öğretim & 78 & 1,4 & 155 & 0,3 & 3.880 .931 & 50,1 & 2,0 & $25.038,3$ \\
\hline Toplam & 5.540 & 100,0 & 45.145 & 100,0 & 7.740 .502 & 100,0 & 8,1 & 171,5 \\
\hline
\end{tabular}

Tablo 2.4. Üniversite türü ve öğrenim türü itibariyle öğrenci sayıları (2018-19)

\begin{tabular}{|c|c|c|c|c|c|}
\hline & Devlet (\%) & Vakıf (\%) & Vakıf MYO (\%) & Toplam (\%) & Sayı \\
\hline Birinci öğretim & 81,9 & 17,9 & 0,2 & 3.089 .285 \\
\hline İkinci öğretim & 94,7 & 4,9 & 0,4 & 100,0 \\
\hline Uzaktan öğretim & 88,5 & 11,5 & 0,0 & 100,0 \\
\hline Açı̈ öğretim & 100 & - & 0,0 & 100,0 \\
\hline Toplam (AÖ hariç) & 84,3 & 15,6 & 0,1 & 100,0 \\
\hline
\end{tabular}

Kaynak: YÖK İstatistik Veri Tabanı, https://istatistik.yok.gov.tr/ 
Tablo 2.5. Üniversite türü ve öğrenim düzeyi itibariyle öğrenci sayıları (2017-18)

\begin{tabular}{|c|c|c|c|c|c|c|c|}
\hline & $\begin{array}{c}\text { Toplamdaki } \\
\text { Oranı (\%) }\end{array}$ & Devlet (\%) & Vakıf (\%) & Toplam & Erkek (\%) & Kadın (\%) & Toplam \\
\hline Önlisans & 25,5 & 85,4 & 14,6 & $\mathbf{1 0 0 , 0}$ & 58,0 & 42,0 \\
\hline Lisans & 61,8 & 84,1 & 15,9 & $\mathbf{1 0 0 , 0}$ & 51,2 & 48,8 & $\mathbf{1 0 0 , 0}$ \\
\hline Yüksek lisans & 10,2 & 81,4 & 18,6 & $\mathbf{1 0 0 , 0}$ & 56,1 & 43,9 & $\mathbf{1 0 0 , 0}$ \\
\hline Doktora & 2,5 & 89,7 & 10,3 & $\mathbf{1 0 0 , 0}$ & 55,6 & 44,4 & $\mathbf{1 0 0 , 0}$ \\
\hline Toplam & 100,0 & 84,3 & 15,7 & $\mathbf{1 0 0 , 0}$ & 53,5 & 46,5 & $\mathbf{1 0 0 , 0}$ \\
\hline
\end{tabular}

Kaynak: YÖK İstatistik Veri Tabanı, https://istatistik.yok.gov.tr/

girişte giriş puanı ve yabancı dil puanı gerekmemesi nedeniyle, vakıf üniversitelerinin payı yüzde 19 civarındadır. Vakıf üniversiteleri payının en düşük olduğu öğrenim düzeyi \%10 ile doktora programlarıdır (Tablo 2.5).

\subsection{Yükseköğrenimden beklenti ve açık öğretim sistemi}

Türkiye 1980 'li yılların ortasından itibaren açı öğretim sistemiyle tanıştı. Her ne kadar 1980 öncesinde mektupla uzaktan eğitim gibi farklı uygulamalar bulunsa da sistemli bir şekildeki açı öğretim daha geç tarihlidir. Avrupa Birliği tam üyeliğine başvuruda, Türkiye'nin Avrupa ülkelerine göre oldukça düşük olan eğitim düzeyini kısa sürede yükseltme ihtiyacı, hükumetleri, göreli olarak çok daha ekonomik olan açık öğretim sistemine yönlendirmiştir (van Vught, van der Wende ve Westerheijden, 2018). Açık öğretim sisteminden başlıca beklentinin yükseköğrenim diplomasına sahip yurttaş sayısını artırmak olup olmadığı konusunda bir netlik olmamakla birlikte, açı öğretimin "bilgi"nin daha ziyade hatırlama ve kavrama aşamalarını hedefleyen bir eğitim niteliğinde olduğu söylenebilir.

Açık öğretim sistemi gibi uzaktan eğitim de giderek artan oranda yükseköğrenim sistemi içinde yer almaya başlamıştır. Yükseköğrenim sistemi içinde, açık öğretim hariç, $\% 2,1$ oranında paya sahip olan uzaktan öğretim uygulaması Türkiye'de nispeten yeni olup, açı öğretim ve örgün öğretimin bir karışımı olarak sunulmakta ve genelde hafta sonunda olmak üzere haftanın belirli bir gününde öğrenciler sınıf ve laboratuvar ortamında yüz yüze eğitim de almaktadır. Açık öğretim büyüklüğünün, yükseköğrenim sisteminin yarısından biraz fazlasına karşıllk gelmesi, hem eğitim programlarının nitelik itibariyle açlk öğretim yaklaşımına uygun olması, hem de dezavantajlı şehirler ve bölgelerde kurulu üniversitelerdeki örgün eğitim programlarının atıl kapasiteyle çalışmalarına neden olması bakımından karmaşık sonuçlara yol açmaktadır. Örgün eğitime yönelik altyapı, yatırım ve cari harcamaların açı öğretim için gerekli olan harcamalara kıyasla kayda değer ölçüde yüksek olduğu dikkate alındığında; açı öğretimin yükseköğrenim sisteminin niteliğini değiștirici bir etkide bulunduğu söylenebilir.

\subsection{Eğitim düzeyleri itibariyle eğitim türleri}

Türk yükseköğrenim sisteminde öğrencilerin yüzde 50'sini açık öğretime kayıtlı olanlar oluştururken; birinci öğretim \%40 ve ikinci öğretim \%9 civarında paylara sahiptir. Uzaktan öğretimin payı ise $\% 1,1$ düzeyindedir. Açı öğretimde sadece önlisans ve lisans eğitimi verilir- ken, uzaktan öğretimde önlisans, lisans ve yüksek lisans eğitimi verilmektedir. Açık öğretimde kayıtlı öğrencilerin $\% 48$ 'i önlisans ve $\% 52$ 'si lisans eğitimi görmektedir. Uzaktan öğretim öğrencilerin oranları önlisansta \%36, lisansta \%44 ve yüksek lisansta \%20 civarındadır (Tablo 2.6).

Tablo 2.6. Öğrenim türü ve öğrenim düzeyi itibariyle öğrenci sayıları (Mayıs 2019)

\begin{tabular}{|c|c|c|c|}
\hline Mayıs 2019 & $\begin{array}{c}\text { Öğrenci } \\
\text { sayısı }\end{array}$ & $\begin{array}{c}\text { Öğrenim türüne } \\
\text { göre dağılım (\%) }\end{array}$ & $\begin{array}{c}\text { Ögrenim düzeyi- } \\
\text { ne göre dağılım } \\
(\%)\end{array}$ \\
\hline Açık Öğretim & 3.880 .931 & 50,1 & 100,0 \\
\hline Önlisans & 1.844 .790 & & 47,5 \\
\hline Lisans & 2.036 .141 & & 52,5 \\
\hline İkinci Öğretim & $\mathbf{6 8 7 . 8 2 9}$ & $\mathbf{8 , 9}$ & $\mathbf{1 0 0 , 0}$ \\
\hline Önlisans & 248.468 & & 36,1 \\
\hline Lisans & 408.062 & & 59,3 \\
\hline Yüksek lisans & 31.299 & & $\mathbf{4 , 6}$ \\
\hline Normal Öğretim & $\mathbf{3 . 0 8 9 . 2 8 5}$ & $\mathbf{3 9 , 9}$ & $\mathbf{1 0 0 , 0}$ \\
\hline Önlisans & 706.613 & & 62,8 \\
\hline Lisans & 1.940 .473 & & 11,2 \\
\hline Yüksek lisans & 346.000 & & 3,1 \\
\hline Doktora & 96.199 & & $\mathbf{1 0 0 , 0}$ \\
\hline Uzaktan Öğretim & $\mathbf{8 2 . 4 5 7}$ & $\mathbf{1 , 1}$ & 35,8 \\
\hline Önlisans & 29.559 & & 43,7 \\
\hline Lisans & 36.023 & & 20,5 \\
\hline Yüksek lisans & 16.875 & & \\
\hline Toplam & 7.740 .502 & $\mathbf{1 0 0 , 0}$ & \\
\hline Kaynak: YOK & & & \\
\hline
\end{tabular}

Kaynak: YÖK İstatistik Veri Tabanı, https://istatistik.yok.gov.tr/

Önlisans öğrencilerinin yaklaşık \%66'sı açık öğretim sisteminde (açık öğretim ve uzaktan öğretim) kayıtlıdır. Türkiye'nin meslek yüksekokulu düzeyindeki ara işgücü ihtiyacını ağırlıklı olarak açık öğretim sistemiyle karşılamaya çalıştı̆̆ı görülmektedir. Lisans eğitiminde ise açı öğretim sisteminin payı yüzde 46 düzeyindedir. Önlisans ve lisans düzeyinde açı öğretimin oldukça yüksek olan payı, ülkenin ihtiyaç duyduğu insan kaynağının eğitiminde bilgi ve becerinin yeri ve bunların hangi düzeyde kazandırıldığı ile ilgili önemli ipuçları da vermektedir (Tablo 2.7).

Yüksek lisans programlarında ikinci öğretimin payı \%8 civarındayken uzaktan öğretimin payı \%4,3’tür. İkinci öğretim ve uzaktan öğretim yüksek lisans programlarının niteliği gereği daha ziyade tezsiz olmaları ve mesleki ağırlıklı olmaları beklenir. Birinci öğretimde öğrenim gören yüksek lisans öğrenci sayısı toplamın \%88'i civarındadır. Doktora programlarının (sanatta yeterlik dahil) tamamı birinci öğretim programı olarak tasarlanmıștır (Tablo 2.7). 
Tablo 2.7. Öğrenim türü ve öğrenim düzeyi itibariyle öğrenci dağılımı (Mayıs 2019)

\begin{tabular}{|c|c|c|c|c|c|}
\hline & $\begin{array}{c}\text { Normal } \\
\text { Öğretim }\end{array}$ & $\begin{array}{c}\text { İkinci } \\
\text { Öğretim }\end{array}$ & $\begin{array}{c}\text { Uzaktan } \\
\text { Öğretim }\end{array}$ & $\begin{array}{c}\text { Açık } \\
\text { Öğretim }\end{array}$ & Toplam \\
\hline Önlisans & 25,0 & 8,8 & 1,0 & 65,2 & 100,0 \\
\hline Lisans & 43,9 & 9,2 & 0,8 & 46,1 & 100,0 \\
\hline Yüksek lisans & 87,8 & 7,9 & 4,3 & - & 100,0 \\
\hline Doktora & 100,0 & - & - & - & 100,0 \\
\hline Sanatta yeterlik & 100,0 & - & - & - & 100,0 \\
\hline
\end{tabular}

Kaynak: YÖK İstatistik Veri Tabanı, https://istatistik.yok.gov.tr/

\section{6 Öğrenim düzeyi itibariyle program çeşidi, program sayısı ve öğrenci sayısı}

Türk yükseköğrenim sistemindeki 5.540 çeşit programın ilişkili oldukları farklı öğrenim düzeylerinde her program çeşidindeki program sayısı farklılık göstermektedir. Program çeşidinin öğrenim düzeyleri arasındaki dağılımında, önlisans programları \%11, lisans programları \%13, yüksek lisans programları $\% 53$, sanatta yeterlik programları $\% 1$ ve doktora programları $\% 22$ oranında paylara sahiptir.

Program çeşitliliği itibariyle eğitim düzeylerinin payları, her bir program çeşidindeki program sayısı dikkate alındığında önemli bir farklılaşma göstermektedir. Bir program çeşidi, birçok üniversitede açılmakta ve böylece 1 çeşit programdan çok sayıda bulunmakta ve bu sayı da önlisanstan doktoraya kadar farklılaşabilmektedir. Örneğin, önlisans programları toplam program çeşidi içinde $\% 11$ paya sahipken, program sayısı bakımından \%29 paya sahiptir. Yine, program çeşidi olarak yüksek lisans programları toplam içinde $\% 53$ oranındayken, program sayısı bakımından \%30 paya sahiptir.

Program çeşidi başına düşen program sayısı en fazla olan öğrenim düzeyleri, sırasıyla önlisans, lisans, doktora, yüksek lisans ve sanatta yeterlik eğitim düzeyleridir. Program çeşidi başına düşen program sayısı ortalama olarak; önlisansta 22, lisansta 17, doktorada 5 , yüksek lisansta 5 ve sanatta yeterlikte 2 civarındadır. Önlisans ve lisans programları, 201 devlet ve vakıf üniversitesinde ve 5 meslek yüksekokulunda (sadece önlisans) açılma imkânına sahipken; lisansüstü programların açılması için gerekli koşullar, başta öğretim üyesi asgari sayısı olmak üzere daha zor sağlandığından, program açılması daha kısıtlı olmaktadır. Lisansüstü program çeşidi başına görece az sayıda program açılmasının ana nedeni, önlisans ve lisans programlarının olduğu akademik birimlerde ve kurumlarda ilave şartlar aranması nedeniyle lisansüstü programların görece daha zor açılmasıdır. Ülkenin ekonomik koşulları göz önünde bulundurulduğunda ikincil derecede etkili neden olarak lisans öğrenimlerini tamamlayan mezun öğ- rencilerin eğitim hayatına devam etmek yerine iș hayatına atılıp ekonomik özgürlüklerini kazanma gayeleri ve dolayısıyla yükseköğrenimin ileri kademelerine ilişkin azalan talep gösterilebilir.

Program sayısı başına düşen öğrenci sayısı en yüksek olan öğrenim düzeyleri, sırasıyla lisans (195), önlisans (75), yüksek lisans (29) ve doktora (16) programlarıdır. Uzaktan öğretim öğrencileri hesaba dahil edilmiş, ancak tamamı önlisans ve lisans programlarında kayıtlı olan açık öğretim öğrencileri hesaba katılmamıştır (Tablo 2.8). Uzaktan öğretim öğrencilerinin önlisans içindeki payı \%3,0, lisans öğrencileri içindeki payı \%1,5 ve yüksek lisans öğrencileri içindeki payı \%4,3'tür.

\subsection{Uluslararası öğrenci sayısı}

Türk yükseköğrenim sistemi, uluslararası öğrenci bağlamında dışa kapalı bir sistemdir. Son yıllarda, yabancı uyruklu öğrenci sayısında bir artış trendi gözükmekle birlikte, özellikle dış politikadaki gelişmeler nedeniyle, yabancı öğrencilerin geldiği coğrafi mecrada bir yoğunlaşma dikkat çekmektedir. 1990'lı yıllarda Sovyetler Birliğinin dağılmasıyla birlikte, Türk cumhuriyetlerinden önemli sayıda yükseköğrenim öğrencisi Türkiye'ye getirilmiştir. Ancak, öğrencilerin seçimi, gelen öğrencilerin kültür farkından kaynaklanan uyum sorunları, Türkiye'de eğitim dilinin Türkçe olması ve gelen öğrencilerin yaşam maliyetlerini karşılamadaki güçlükleri başta olmak üzere birçok nedenden dolayı proje ciddi bir başarı gösterememiştir (Alsharari, 2018; Johnson, 2015; Ergin ve Türk, 2010; Özkan, 2007; Kavak ve Baskan, 2001; Karabayev ve Tutkun, 2001).

2017/18 akademik yılında, Türkiye'deki uluslararası öğrencilerin sayısı 125.030 olarak tahmin edilmektedir. Yabancı uyruklu öğrencilerin geldiği coğrafi bölgelerde Ortadoğu \%31, Türk Cumhuriyetleri \%30, Afrika \%13 ve Asya \%10 civarında paya sahiptir. Batı Avrupa, Balkanlar ve Doğu Avrupa birlikte \%13,5 oranında paya sahiptir. Türkiye'deki yükseköğrenim kurumlarında öğrenim gören uluslararası öğrencilerin toplam öğrenciler (açık öğretim hariç) içindeki oranı \%3,2 düzeyindedir. Türk Cumhuriyetlerinden gelen öğrenciler ile Batı Avrupa'daki Türk soylu öğrencilerin ağırlığı ve Türkiye'nin sağladığı burslar dikkate alındığında; istatistiksel olarak uluslararası öğrenci statüsünde olanların önemli bir kısmının çeşitli teşviklerle Türkiye'ye geldikleri sonucuna varılabilir. Bu bakımdan, Türk yükseköğrenim sisteminin, gelişmiş ülke sistemleriyle karşılaştırıldığında uluslararası öğrenciler bakımından cazibeli olmadığı söylenebilir.

Tablo 2.8. Öğrenim düzeyi itibariyle program çeşidi, program sayısı ve öğrenci sayısı (Mayıs 2019)

\begin{tabular}{|c|c|c|c|c|c|c|c|c|}
\hline & $\begin{array}{l}\text { Program } \\
\text { çeşidi }\end{array}$ & \% dağılım & $\begin{array}{c}\text { Program } \\
\text { sayısı }\end{array}$ & \% dağılım & Öğrenci sayısı & \% dağılımı & $\begin{array}{l}\text { Program sayısı / Prog- } \\
\text { ram çeşidi }\end{array}$ & $\begin{array}{l}\text { Öğrenci sayısı / } \\
\text { program sayısı }\end{array}$ \\
\hline Önlisans & 600 & 10,8 & 13.189 & 29,2 & 984.640 & 25,5 & 22 & 74,7 \\
\hline Lisans & 733 & 13,2 & 12.231 & 27,1 & 2.384 .558 & 61,8 & 16,7 & 195,0 \\
\hline Yüksek lisans & 2.907 & 52,5 & 13.714 & 30,4 & 394.174 & 10,2 & 4,7 & 28,7 \\
\hline Doktora & 1.300 & 23,5 & 5.873 & 13 & 96.199 & 2,5 & 4,8 & 16,4 \\
\hline Toplam & 5.540 & 100,0 & 45.145 & 100 & 3.859 .571 & 100,0 & 8,1 & 85,5 \\
\hline
\end{tabular}


Tablo 2.9. Türkiye'de öğrenim görmekte olan yabancı uyruklu öğrenciler (2017/2018)

\begin{tabular}{|c|c|c|}
\hline Bölge & Toplam & Yüzde \\
\hline Ortadoğu & 38.817 & 31,0 \\
\hline Türk Cumhuriyetleri & 37.775 & 30,2 \\
\hline Afrika & 16.402 & 13,1 \\
\hline Asya & 12.381 & 9,9 \\
\hline Batı Avrupa & 8.189 & 6,5 \\
\hline Balkanlar & 7.370 & 5,9 \\
\hline Doğu Avrupa & 1.399 & 1,1 \\
\hline KKTC & 986 & 0,8 \\
\hline Kuzey Amerika & 686 & 0,5 \\
\hline Latin Amerika & 290 & 0,2 \\
\hline Okyanusya & 106 & 0,1 \\
\hline Diğer & 629 & 0,5 \\
\hline Genel Toplam & 125.030 & 100,0 \\
\hline \multicolumn{2}{|c|}{ Kaynak: YÖK Istatistik Veri Tabanı, https://istatistik.yok.gov.tr/ }
\end{tabular}

\subsection{Değişim programlarına katılan öğrenci sayısı}

Türk yükseköğrenim sistemi, Erasmus değişim programı yoluyla önemli bir tecrübeye sahip olmuştur. Mevlâna değişim programı, Erasmus'tan esinlenerek geliştirilmiş, ancak Erasmus gibi sınırlı bir coğrafyaya veya belirlenmiş bir odak nokta yerine bütün dünyaya yaygınlaştırılmıştır. Ne var ki, Mevlâna programının genel amaçlı olarak bütün ülkelere açılması, hedef kitle ve amaçlanan çıtılar bakımından bir belirsizliğin olduğuna da işaret etmektedir (Huisman, Juijten-Lub ve vand der Wende, 2015; Güzel, 2014). Kaynakların sınırlı olması nedeniyle, Mevlâna programının başarısı da sınırlı kalmıştır.

Tablo 2.10. Uluslararası değişim programlarına katılan yerli ve yabanc uyruklu öğrenciler (2018/2019)

\begin{tabular}{|c|c|c|c|c|}
\hline & Devlet & Vakıf & Vakıf MYO & Toplam \\
\hline Mevlâna Giden & 110 & - & - & 110 \\
\hline Erasmus Giden & 4.387 & 1.319 & - & 5.706 \\
\hline Toplam & 4.497 & 1.319 & - & 5.816 \\
\hline & & & & \\
\hline Mevlâna Gelen & 328 & 2 & - & 330 \\
\hline Erasmus Gelen & 1.800 & 1.223 & 1 & 3.024 \\
\hline Toplam & 2.128 & 1.225 & 1 & 3.354 \\
\hline
\end{tabular}

Kaynak: YÖK İstatistik Veri Tabanı, https://istatistik.yok.gov.tr/ Tablo 2.11. Öğretim elemanı sayıları, 2002-2003

\begin{tabular}{|c|c|c|c|c|c|c|}
\hline & Profesör & Doçent & Dr. Öğr. Üyesi & Öğr.Gör. & Araş.Gör. & Toplam \\
\hline & 9.427 & 4.957 & 11.645 & 16.648 & 26.557 & 69.234 \\
\hline Devlet & 615 & 262 & 711 & 2.489 & 823 & 4.900 \\
\hline & 10.042 & 5.219 & 12.356 & 19.137 & 27.380 & 74.134 \\
\hline & & & & & & \\
\hline Vakıf & 13,5 & 7,0 & 16,7 & 25,8 & 36,9 & 100,0 \\
\hline Dnvanın toplam içindeki yeri & 93,9 & 95,0 & 94,2 & 87,0 & 97,0 & 93,4 \\
\hline Kadin oranı & 9,1 & 6,3 & 13,4 & 30,3 & 40,9 & 37,8 \\
\hline
\end{tabular}

Kaynak: YÖK İstatistik Veri Tabanı, https://istatistik.yok.gov.tr/

Tablo 2.12. Öğretim elemanı sayıları (Haziran 2019)

\begin{tabular}{|c|c|c|c|c|c|c|}
\hline & Profesör & Doçent & Dr. Öğr. Üyesi & Öğr.Gör. & Araş.Gör. & Toplam \\
\hline Devlet & 22.460 & 13.579 & 31.775 & 29.405 & 44.962 & 142.181 \\
\hline Vakıf & 4.284 & 1.985 & 7.859 & 7.398 & 3.529 & 25.055 \\
\hline Toplam & 26.744 & 15.564 & 39.634 & 36.803 & 48.491 & 167.236 \\
\hline Unvanların toplam içindeki yeri & 16,0 & 9,3 & 23,7 & 22,0 & 29,0 & 100,0 \\
\hline Devlet üniversiteleri oranı & 84,0 & 87,2 & 80,2 & 79,9 & 92,7 & 85,0 \\
\hline Kadın oranı & 31,6 & 39,6 & 43,5 & 50,2 & 50,7 & 44,8 \\
\hline
\end{tabular}

Kaynak: YÖKSiS Veri Tabanı. 
mından iki grup arasındaki organik ilişkinin dengeli götürülmesi gerekmektedir (Tablo 2.9 ve Tablo 2.10).

Türk yükseköğrenim sisteminde lisansüstü eğitimler, genelde lisans programlarındaki öğretim üyeleri tarafından yürütülmektedir. Enstitü ve araştırma merkezleri kadrolarında çalışan öğretim üyesi sayısı, toplam sayı içinde çok düşüktür. 2019 Mart sonu verilerine göre, enstitü, araştırma merkezleri ve rektörlük gibi birimlerde kadrolular hariç tutulduğunda, lisans programlarında kadrolu olan öğretim elemanlarının unvanlar itibariyle dağıllminda profesörler \%21, doçentler \%11, Dr. öğretim üyeleri \%25 paya sahipken; öğretim görevlilerinin payı $\% 6$ ve araștırma görevlilerinin payı \%37 civarındadır. Önlisans programlarında kadrolu akademik personelin \%77'si öğretim görevlisi iken, \%17'si Dr. Öğr.Üyesi, \%2'si doçent ve \%2'si profesör unvanlıdır (Tablo 2.11).

Tablo 2.13. Öğretim elemanı sayıları (Mart 2019)

\begin{tabular}{|c|c|c|c|c|c|c|}
\hline & Profesör & Doçent & $\begin{array}{c}\text { Dr. Öğr. } \\
\text { Üyesi }\end{array}$ & $\begin{array}{l}\text { Öğretim } \\
\text { Görevlisi }\end{array}$ & $\begin{array}{l}\text { Araştırma } \\
\text { Görevlisi }\end{array}$ & Toplam \\
\hline Önlisans & 382 & 383 & 2.988 & 13.244 & 134 & 17.131 \\
\hline Lisans & 29.389 & 15.334 & 34.996 & 8.631 & 50.799 & 139.149 \\
\hline Toplam & 29.771 & 15.717 & 37.984 & 21.875 & 50.933 & 156.280 \\
\hline
\end{tabular}

\begin{tabular}{|c|c|c|c|c|c|c|}
\hline \multicolumn{7}{|c|}{ Akademik unvanların eğitim düzeyi içindeki dağılımı (\%) } \\
\hline & Profesör & Doçent & $\begin{array}{c}\text { Dr. Öğr. } \\
\text { Üyesi }\end{array}$ & $\begin{array}{c}\text { Öğretim } \\
\text { Görevlisi }\end{array}$ & $\begin{array}{c}\text { Araştırma } \\
\text { Görevlisi }\end{array}$ & Toplam \\
\hline Önlisans & 2,2 & 2,2 & 17,4 & 77,3 & 0,8 & 100,0 \\
\hline Lisans & 21,1 & 11,0 & 25,2 & 6,2 & 36,5 & 100,0 \\
\hline Toplam & 19,0 & 10,1 & 24,3 & 14,0 & 32,6 & 100,0 \\
\hline
\end{tabular}

Akademik unvanların eğitim düzeyleri arasındaki dağılımı (\%)

\begin{tabular}{|c|c|c|c|c|c|c|}
\hline Önlisans & 1,3 & 2,4 & 7,9 & 60,5 & 0,3 & 11,0 \\
\hline Lisans & 98,7 & 97,6 & 92,1 & 39,5 & 99,7 & 89,0 \\
\hline Toplam & 100,0 & 100,0 & 100,0 & 100,0 & 100,0 & 100,0 \\
\hline
\end{tabular}

Kaynak: YÖKSIS Veri Tabanı; YÖK Istatistik Veri Tabanı, https://istatistik.yok.gov.tr/ Program çeşidi, program sayısı, öğretim elemanı sayısı ve öğrenci sayısı gibi parametrelerin birbiriyle ilişkisine bakıldığında; ortalama sayılar bakımından Türk yükseköğreniminin ciddi bir handikap içinde olmadığı söylenebilir. Buna göre program çeşidi başına düşen öğretim elemanı sayısı ortalama 38, öğretim üyesi sayısı ise ortalama 19 civarındadır. Program sayısı başına düşen öğretim elemanı sayısı ortalama 3,8, öğretim üyesi sayısı ise ortalama 1,9'dur (Tablo 2.12).

Açı öğretimde kayıtlı öğrenciler hariç tutulduğunda, öğretim elemanı bașına düșen öğrenci sayısı ortalama 23, öğretim üyesi başına düşen öğrenci sayısı ise ortalama 47 civarındadır. Önlisans, lisans ve lisansüstü öğrenim birlikte dikkate alındığında (açık öğretimde kayıtlı öğrenciler hariç), öğrencisi olan programlarda, program sayısı başına düşen öğrenci sayısı ortalama 89 civarındadır (Tablo 2.12).
Tablo 2.14. Program sayısı, öğretim elemanı sayısı ve öğrenci sayısı (açık öğretimde kayıtlılar hariç) ilişkisi (Haziran 2019)

\begin{tabular}{|l|l|}
\hline & $\begin{array}{l}\text { Kişi / } \\
\text { Adet }\end{array}$ \\
\hline $\begin{array}{l}\text { Program çeşidi (öğrencisi olan) başına düşen ortalama öğretim } \\
\text { elemanı sayısı }\end{array}$ & 37,8 \\
\hline $\begin{array}{l}\text { Program çeşidi (öğrencisi olan) başına düşen ortalama öğretim } \\
\text { üyesi sayısı }\end{array}$ & 18,5 \\
\hline $\begin{array}{l}\text { Program sayısı (öğrencisi olan) başına düşen ortalama öğretim } \\
\text { elemanı sayısı }\end{array}$ & 3,8 \\
\hline $\begin{array}{l}\text { Program sayısı (öğrencisi olan) başına düşen ortalama öğretim üyesi } \\
\text { sayısı }\end{array}$ & 1,9 \\
\hline Öğretim elemanı başına düşen ortalama öğrenci sayısı & 23,1 \\
\hline Öğretim üyesi başına düşen ortalama öğrenci sayısı & 47,1 \\
\hline
\end{tabular}

Kaynak: YÖKSIS Veri Tabanl; YÖK İstatistik Veri Tabanı, https://istatistik.yok.gov.tr/

\subsection{0 Üniversite yerleştirme ve boş kalan kontenjanlar}

Yükseköğretim kurumları sınavı (YKS), Türk vatandaşlarının üniversite eğitimi almalarında merkezi yerleștirme işlevi görür. 2018 YKS sınavı sonucunda örgün eğitimde lisans programlarına yerleşenlerin oranı \%17, önlisans programlarına yerleșenlerin oranı \%13 ve açık öğretim programlarına yerleșenlerin oranı \%6 civarındadır. Dolayısıyla, başvuranların \%36'sı sınav sonucunda bir yükseköğrenim programına yerleşmiş durumdadır. YKS sınavina başvuranlar, son sınıf düzeyinde olanlar, mezun olup ancak daha önce yerleşmemiş olanlar, bir yükseköğrenim kurumunu bitirmiș olanlar ve daha önce yerleșmiș olanların tamamını kapsamaktadır. Üniversite seçme ve yerleştirme sınavı sonucu tercih hakkı olanların 2017 yılında \%54'ü ve 2018 yllında ise \%69'u program tercihinde bulunmuştur. Bu da öğrencilerin seçici davrandığını, yerleșebilecekleri programlar varken tercihte bulunmadıklarını göstermektedir (Tablo 2.13).

Üniversite eğitiminde en fazla tercih edilen programlar, sırasıyla istihdam imkânı ve toplumsal saygınlığı yüksek programlar olmaktadır. Örneğin hemşirelik, mimarlık, IT gibi alanlarda istihdam kaygısı öne çıkarken, tıp, hukuk, mühendislik ve mimarlık programlarında sosyal statü ilk sırada etkili olmaktadır. Fizik, kimya, biyoloji ve matematik programlar fen fakültelerinin yanısıra eğitim fakültelerinde de yer almaktaydı. Öğretmenlik hakkının istihdama etkisi nedeniyle fen fakültelerinin puanları ve tercih edilme oranları hayli düşük olmaktaydı. YÖK'ün eğitim fakültelerindeki alan eğitimlerini kapatarak fen fakültelerine devretmesi sonucunda, fen fakültelerine olan talepte kısmen bir artış oldu, ancak istihdam imkânlarının gelișmemesi nedeniyle bugün hala fizik, kimya, biyoloji ve matematik (FKB-M) programlarında ciddi oranda kontenjan boşlukları mevcuttur. (YÖK, 2018 ve 2019).

Doğa bilimlerinin yaşadığı bu irtifa kaybı beșerî bilimler ve sosyal bilimler için de geçerlidir. Doğa bilimleriyle aynı zaman diliminde dil, edebiyat, sosyoloji, felsefe, arkeoloji gibi beșerî bilim programları da hem eğitim fakültesi ve edebiyat fakültesi ayırımından hem de istihdamın sınırlı olmasından kaynaklanan bir tercih düșüklüğü yașamıștır. Sosyal bilimler için ise son birkaç yıldan bu yana alarm zilleri çalmaya bașlamıștır. İktisat, kamu yönetimi, siyaset 
bilimi, işletme, maliye gibi programlar istihdam imkânlarının sınırlı olması nedeniyle giderek daha az tercih edilmeye başlamış ve metropollerin dışındaki şehirlerde ciddi kontenjan boşlukları oluşmaya başlamıştır.

Yükseköğrenim programlarında kontenjanların dolmamasında diğer önemli üç faktör, açık öğretim ve uzaktan öğretim programlarının açılması, metropol üniversitelerinin artırılan kontenjanları ve metropollerde sayısı hızla artan vakıf üniversiteleridir. Yükseköğrenim görecek adaylar, Şırnak, Ardahan veya Artvin üniversitelerinden birinin örgün eğitim diploması ile Anadolu, İstanbul veya Atatürk gibi köklü üniversitelerinden birinin açı öğretim veya uzaktan öğretim diplomalarının piyasadaki ve toplumdaki karşılığını değerlendirmektedir. Metropollerde özellikle devlet üniversitelerinde çok fazla sayıda akademik kadro bulunması nedeniyle, buralardaki öğrenci kontenjanı da sürekli artırıldığı için taşradaki devlet üniversitelerine yönelim azalmaktadır. Vakıf üniversitelerinin sayısındaki artış, düşük puan aldığı için metropollerdeki üniversitelere yerleşemeyen adaylara yeni bir seçenek sunarken, aynı zamanda taşradaki devlet üniversitelerine yönelmesi beklenen potansiyeli de düşürmektedir. Sonuçta, yükseköğrenime erişimi kolaylaştırmak için bütün illerde ve bazı büyük ilçelerde yükseköğrenim kurumları açılması ve ilçelerde yükseköğrenim programları açılmas1, sunulan programdan mezun olanın istihdam imkânının sınırlı olması ve transfer edilebilir beceri ve yetkinlik kazandırma potansiyelinin düşük olması gibi faktörler nedeniyle arzulanan sonucu tam olarak verememektedir (Özer 2019 ve 2018; Cedefop, 2018; Günay ve Özer, 2016 ve 2014).

Tablo 2.15. YKS'ye başvuran ve yükseköğrenim programlarına yerleşenler

\begin{tabular}{|c|c|c|c|c|c|}
\hline 2018 & Başvuran & \multicolumn{4}{|c|}{ Yerleşen (\%) } \\
\hline & Lisans & Önlisans & $\begin{array}{c}\text { Açık } \\
\text { öğretim }\end{array}$ & Toplam \\
\hline Lise çıkışılır & 1.266 .594 & 24,0 & 10,9 & 5,5 & 40,4 \\
\hline Meslek lisesi çıkışılılar & 853.199 & 5,0 & 17,1 & 6,4 & 28,4 \\
\hline $\begin{array}{c}\text { İmam hatip lisesi } \\
\text { çıkışılır }\end{array}$ & 234.657 & 15,8 & 13,0 & 9,1 & 37,9 \\
\hline $\begin{array}{c}\text { Genel toplam (diğer } \\
\text { dahil) }\end{array}$ & 2.381 .412 & 16,6 & 13,3 & 6,1 & 36,0 \\
\hline
\end{tabular}

Kaynak: YÖK İstatistik Veri Tabanı, https://istatistik.yok.gov.tr/

Tablo 2.16. Üniversite mezunu ve halen kayıtlı olanların başvuru içindeki oranı (\%)

\begin{tabular}{|c|c|c|c|}
\hline $\mathbf{2 0 1 8}$ & $\begin{array}{c}\text { Bir yükseköğrenim } \\
\text { kurumunu bitirmiş } \\
\text { olanlar }\end{array}$ & $\begin{array}{c}\text { Daha önce } \\
\text { yerleşmiş } \\
\text { olanlar }\end{array}$ & Toplam \\
\hline Lise çıkışlılar toplamı & 10,0 & 20,9 & 30,9 \\
\hline $\begin{array}{c}\text { Meslek lisesi çıkışılır } \\
\text { toplamı }\end{array}$ & 6,3 & 20,1 & 26,4 \\
\hline İmam hatip liseleri & 3,0 & 16,5 & 19,5 \\
\hline $\begin{array}{c}\text { Genel toplam (diğer } \\
\text { dahil) }\end{array}$ & 8,0 & 20,3 & 28,3 \\
\hline
\end{tabular}

Kaynak: YÖK İstatistik Veri Tabanı, https://istatistik.yok.gov.tr/

YKS'ye başvuranların \%28'i daha önce bir yükseköğrenim kurumundan mezun olanlar ile hali hazırda bir yükseköğrenim programında kayıtlı olanlardan oluşmaktadır.
Sınava giren bu kitlenin sınav sonrasında yerleşme oranı, diğer başvuran gruplara göre daha yüksek değildir (Tablo 2.14).

\section{3. ÜNIVERSITE SINIFLAMASI VE EĞiTIMIN MESLEK VE UNVAN İLE İLiŞKISI}

YÖK, birkaç yıldan bu yana üniversiteleri çeşitli sınıflamalara tabi tutarak yükseköğrenimi yönlendirmeye, ihtisaslaşmaya teşvik etmektedir. YÖK, birçok üniversiteyi tematik üniversite ve araştırma üniversitesi olarak ilan etmiş durumdadır. YÖK'ün tematik üniversiteleri belirlerken, sınırlayıcı bir çerçeve getirmemesi, mekanizma ve araçları belirlememesi bir yandan özgünlüğe ve esnekliğe imkân verirken, diğer yandan bu konuda tecrübesi olmayan üniversitelerin belirsizlikle karşılaşmalarına da neden olmaktadır. YÖK'ün yaptığı üniversite sınıflamasında, üniversitenin araştırma yetkinliği, ekonomik katkı ve ticarileşme düzeyi, girişimcilik ve yenilikçilik kültürü, paydaşlarla işbirliği ve etkileşim ile fikri mülkiyet kapasitesi göstergeleri önemli rol oynar. Nitekim TÜBİTAK bu 5 parametreye dayalı olarak toplam 23 değişken üzerinden üniversiteleri yenilikçi ve girişimci üniversite sıralamasına ve derecelemesine tabi tutmaktadır. Uluslararası alanda, üniversitelerin derecelendirilmesi uzun yıllardan beri yapılmaktadır. Türkiye'de üniversiteleri dereceleyen sadece bir oluşum bulunmaktadır (http://www.urapcenter. org). Üniversitelerin derecelendirilmesinde TÜBİTAK'ın geliştirdiği yenilikçi ve girişimci üniversite endeksi finansal destekle sonuçlanan önemli bir uygulamadır. Yine YÖK'ün akademisyenlerin yıllık faaliyet performanslarına göre akademik teşvik ödemesi de üniversite faaliyetlerinin artmasında ve görünür kılınmasında önemli bir itki olmuştur.

Son birkaç yıldan bu yana Türkiye'de Sanayi ve Teknoloji Bakanlığı, TÜBİTAK ve YÖK gibi ulusal düzeydeki düzenleyici ve icracı otoriteler, üniversitelerin sanayi ile işbirliğini geliştirme, ülkenin Ar-Ge altyapısını güçlendirme ve yenilik ve ticarileşme yönünde önemli adımlar atmaktadır. Teknoparklar ve teknoloji transfer ofisleri, akademisyenlerin Ar-Ge projelerine ve iş dünyasına yönelmelerinde ciddi bir motivasyon sağlamaktadır. Ne var ki, geçmişten gelen kültürün etkisiyle akademisyenlerin sanayi ile işbirliği düzeyleri planlandığı ve arzulandığı düzeyde değildir. Bunda, bir yandan akademisyenlerin proje ve Ar-Ge konseptlerine aşina olmamaktan kaynaklanan mesafeleri, diğer yandan proje fonlamasında yeterli kaynak bulunmaması ve kaynakları kullandıranların bu kültüre yeterince sahip olmaması ve ulusal otoritelerin belirledikleri öncelikleri benimsememeleri belirleyici olmaktadır. Mesela, TÜBİTAK ve KOSGEB gibi kuruluşlar, yeni iş yeri açma, fikirlerin ticarileşmesi, akademisyenlerin imalat ve ticaret alanlarına yönlendirilmesi için, mali desteğin yanısıra vergi ve harç istisnalarını kapsayan birçok mekanizma ve araçlar geliştirmektedir. Teknoparklarda firma kurmaya teşvik edilen ve finanse edilen mezunların ve akademisyenlerin geliştirdiği fikirler, tasarımlar 
ve ürünler pazara çıktığında, başta kamu kesimi karar alıclları gelmek üzere, başlangıç kurgusundaki teşviki görememektedir. Ülkenin girişimci ve yenilikçi potansiyelinin oluşturulması ve kapasitesinin geliştirilmesi, süreç içindeki kamu karar alıcılarının paralel bakışaçılarına sahip olmaması nedeniyle akim kalmaktadır. Kamu alımlarının ve ihalelerinin yeni girişimleri özendirecek araçlar geliştirmesi gerekmektedir (Lombardi ve diğ., 2017; Phusavat ve diğ., 2011; Saginova ve Belyansky, 2008).

Üniversitelerin tematik veya araştırma odaklı sınıflandırmasında, bu üniversitelerdeki mevcut eğitim ve araştırma programlarındaki kapasite belirleyici olacaktır. Bu çalışmada, UNESCO'nun geliștirdiği standart eğitim sınıflaması dikkate alınarak Türk yükseköğrenim sistemindeki önlisanstan doktoraya kadar olan programlar betimleyici bir çerçevede analiz edilmiştir. Esasen, eğitim programları ile meslekler ve ekonomik faaliyetler arasında ulusal düzeyde bir planlama yapılır. Bunu geçmişte Devlet Planlama Teşkilatı koordinasyon kurumu olarak gerçekleştirirdi. Günümüzde Cumhurbaşkanı Hükumet Sisteminde ise bu konudaki karar ve icra makamları henüz netleşmemiştir. Gelişen teknoloji ve iş biçimleri ile birlikte, yakın gelecekte ortadan kalkacak meslekler ve faaliyetler, yeni meslekler ve faaliyetler ve buna uyum sağlayacak eğitim içeriği ve teknolojileri bütün ülkeler bakımından kritik önemdedir. Türkiye'nin yükseköğrenim sistemini bu bakışaçısıyla irdelemesi ve bilgi toplumunun temelini yükseköğrenim sisteminin oluşturacağı kabulüyle konuyu ele alması gerekiyor.

Ülkelerin bilgi toplumu olma yönündeki çalışmalarında bilgiyi üretme kapasitesinin artırılmasının yanısıra kaliteli mesleki, teknik veya akademik yükseköğrenim mezun oranının artırılmasıyla bilgiyi kullanabilecek/işleyebilecek işgücünün artırılması da önem taşımaktadır. Bilginin ve yayılımının önemli boyutlarından biri olarak kabul gören eğitimli işgücü ülkelerin bilgi toplumu olma yolunda kat ettikleri yada edecekleri mesafeyi belirleyen önemli etmenlerden birisidir (Chen and Dalhman 2004).

\subsection{ISCED, ISCO ve ISIC sınıflamaları}

Uluslararası Standart Meslek Sinıflaması (ISCO), Uluslararası Çalışma Örgütünün (ILO) sorumluluğunda yürütülen bir sinıflamadır. ISCO, bir ișteki görev ve sorumluluklar çerçevesinde meslek sinıflaması yapılırken çeşitli ilkelere dayanır (ILO, 1988 ve 2008). Uluslararası karşılaştırmalarda ve sınıflamalarda mesleklerin aynı kurallara göre tasnifi kritik önemdedir. ISCO'nun ana amacı, işlere ve mesleklere ilişkin bilgilerin uluslararası açıdan raporlanması ve karşılaştırılması için bir zemin oluşturmaktır. ISCO'da iş ve meslek kavramları tanımlanmış ve programlar ISCED sınıflamasında dikkate alınmıştır. Dolayısıyla, ISCED'de eğitim programlarının sınıflandırılmasında, ekonomik faaliyetlerin niteliği ve bu faaliyetleri icra edenlerin sahip olduğu vasıflar dikkate alınmıştır. ISCED, ISCO ve ISIC (Uluslararası Standart Ekonomik Faaliyet Sinıflaması) sinıflamalarında yaygın olarak kullanılan or- tak terimlerin tanımları aşağıda verilmektedir:

İş: 'bir işveren namına veya kendi hesabına çalışmak da dahil olmak üzere bir kişi tarafından gerçekleştirilen veya gerçekleştirilmesi öngörülen görev ve sorumluluklar seti’ olarak tanımlanır.

Meslek: Bir meslek, içerisindeki 'ana görev ve sorumlulukların yüksek derecede benzerliği ile nitelenen bir iş setidir'. Bir kişi, geçmiş, mevcut veya gelecekteki bir işle olan ilişkisi bakımından bir meslekle ilişkilendirilebilir.

ISCO-08, meslekleri gruplar halinde düzenlerken iki temel kriter kullanır: beceri seviyesi ve beceri uzmanlaşmas1.

Beceri: 'verilen işin görevleri ve sorumlukları yerine getirme kabiliyeti'.

Beceri düzeyi: 'gerçekleștirilecek görevler ve sorumluluklar dizisinin ve karmaşıklığının bir fonksiyonudur'.

Beceri uzmanlaşması: 'gerekli bilgi alanı, kullanılan araçlar ve makineler, kullanılan veya üzerinde çalışılan malzemeler ve üretilen mal ve hizmet çeşitleri' olarak düşünülür.

ISCO içindeki beceri uzmanlığı kavramı, ISCED'deki eğitim ve öğretim alanlarıla bazı benzerlikler göstermektedir. Bununla birlikte, ISCO ve ISCED, farklı istatistiksel birimleri farklı kriterler kullanarak sınıflandırır. ISCO işleri gerçekleştirmek için gerekli beceri seviyesine ve uzmanlığa bağlı olarak işleri sınıflandırırken; ISCED Eğitim ve Öğretim Alanları, konular bakımından eğitim programlarını ve yeterliliklerini sınıflandırır. Bu nedenle, her ne kadar iki sınıflama arasında bağlantılar açıcça var olsa da; iki sınıflamadaki meslek grupları ve alan grupları arasında doğrudan bir uyumluluk her zaman olmayabilir.

Uluslararası Standart Ekonomik Faaliyet Sinıflaması (ISIC), uluslararası kabul görmüş kurallara göre ekonomik faaliyetlerin sınıflandırılmasını amaçlar (UNSD, 2008). Ülkeler arası karşılaştırma ve sınıflamalarda, bir ülkenin insan gücü planlamasında, mevcut işlerin ve faaliyetlerin sınıflandırılması karar süreçleri için önemli bir girdi oluşturur. ISCO ve ISIC sınıflamalarını tamamlayıcı diğer bir sınıflama ISCED sınıflamasıdır.

Uluslararası Standart Eğitim Sınıflaması (ISCED), uluslararası karşılaştırılabilir eğitim istatistiklerinin toplulaştırılması, derlenmesi ve analiz edilmesi için kullanılan bir çerçevedir. ${ }^{4}$ ISCED, eğitim programlarının ve bunlara ilişkin yeterliliklerin eğitim alanlarına ve seviyelerine göre düzenlenmesinde referans sınıflamadır. İlk kez 1970'lerin ortalarında Birleşmiş Milletler Eğitim, Bilim ve Kültür Örgütü (UNESCO) tarafından geliştirilen ISCED, iki kez revize edilmiş olup, ikinci revizyon 2011 yllında yapılmış, esas olarak eğitim programları (ISCED-P) seviyelerindeki değişikliklere yoğunlaşmış ve ilk kez yeterliliklere (ISCED-A) dayalı olarak, kişinin sahip olduğu eğitimin

${ }^{4}$ Bu çalışmada ISCED'e ilişkin açıklamalar Toprak ve diğ. 2018'den alınmıştır. http://www.yuksekogretim.org/ozet_2018001011.asp 
seviye itibariyle sınıflandırılması olarak takdim edilmiștir. Ortak bir uluslararası sınıflamanın olması, karșılaștırılabilir verilerin toplanmasının yanısıra, ülkeler arasında bu sınıflamanın tutarlı bir șekilde uygulanmasını sağlamak için açık ilkelerin geliştirilmesini de beraberinde getirmektedir.

ISCO ve ISIC sınıflamalarının bu çalışmada betimsel olarak sunulmakla yetinilmiștir. Halihazırda yayımlanma așaması için hazırlıkları süren, ISCED geniș, dar ve ayrıntılı alanlarına yönelik analizleri kapsayan iki çalıșma bulunmaktadır. Dolayısıyla, ISCED'in ISCO ve ISIC ile ilişkisi sözkonusu iki çalışmada sektör ve alan bazında daha somut olarak ele alınabilecektir.

\subsection{ISCED sınıflama birimleri}

ISCED'deki sınıflamanın temel birimleri, eğitim programları ve bunlarla ilişkili olan yeterliliklerdir. Bunlar, ISCED Eğitim ve Öğretim Alanları'nda (ISCED-F) yer alan sınıflama birimleri ile aynıdır. Bu çalışmada, YÖK veri tabanında yer alan programlar sınıflandırılırken, ISCED metodolojisi esas alınacaktır. Bu nedenle, ISCED bağlamında eğitim programı ve yeterlilik sözcüklerinin tanımlanması gerekiyor.

Eğitim programı: Belirli bir zaman periyodunda, önceden belirlenmiş öğrenme amaçlarına ulaşmak veya önceden belirlenmiş spesifik eğitim görevleri dizisini yerine getirmek için tasarlanmıș ve organize edilmiș birbiriyle uyumlu eğitim faaliyetleri seti veya birbiriyle uyumlu eğitim faaliyetleri ardışık dizisidir.

Eğitim faaliyetleri: Öğrenmeyle sonuçlanması niyetini taşıyan bazı iletişim biçimlerini kapsayan amaçlanmış faaliyetlerdir.

Yeterlilik: Bir eğitim programının başarılı bir şekilde tamamlandığını kanıtlayan ve genellikle bir doküman formatında olan resmi onaydır. Derslerin tekil bazda başarıyla tamamlandığını gösteren krediler (örneğin; modüller veya konular) ISCED içerisinde yeterlilik olarak kabul edilmez. Bu gibi durumlarda, bir programın tamamının müfredatını kapsayan ve/veya süre bakımından denk olan yeterli miktardaki krediler veya konular yeterliliği ifade edecektir.

Mesleki eğitim: Öğrenenlerin belirli bir mesleğe, zanaata veya meslek sınıfına ya da zanaat sınıfına özgü bilgi, beceri ve yetkinlikleri kazanabilmeleri için tasarlanan programlar. Mesleki eğitim, çalışma-bazlı bileşenlere sahip olabilir. Bu tür programların başarıyla tamamlanması, işgücü piyasasıyla uyumlu mesleki yeterliliklere götürür. $\mathrm{Bu}$ yeterlilikler, ilgili ulusal otoriteler ve/veya işgücü piyasası tarafından meslek-yönelimli olarak kabul edilen yeterliliklerdir.

Genel eğitim: $\mathrm{Bu}$ programlar, öğrenenlerin genel bilgi, beceriler ve yetkinliklerinin yanısıra okuryazarlık ve rakamsal becerilerini de geliştirmek için tasarlanır. $\mathrm{Bu}$ programlar, çoğu kez öğrencileri aynı veya daha yüksek
ISCED seviyelerindeki daha ileri düzey eğitim programları için hazırlamak ve hayat boyu öğrenmeyi yerleștirmek amacı tașırlar.

ISCED sınıflaması; geniş alanlar (en üst seviye), dar alanlar (ikinci seviye) ve ayrıntılı alanlar (üçüncü seviye) olmak üzere üç-seviyeli hiyerarşi olarak tasarlanmıș ve dört basamaklı kodlama şeması kullanılmıștır. 11 adet geniş alan, 29 adet dar alan ve 80 adet civarında ayrıntılı eğitim ve öğretim alanı bulunmaktadır.

\begin{tabular}{|c|c|c|}
\hline Seviye & Alan Kategorileri & Alan Sayısı \\
\hline 1'inci seviye & Geniş Alan & 11 \\
\hline 2'nci seviye & Dar Alan & 29 \\
\hline 3'üncü seviye & Ayrıntılı Alan & $\cong 80$ \\
\hline
\end{tabular}

Ayrıntılı alanlar (ISCED sınıflamasının üçüncü hiyerarșik seviyesi), esas itibariyle üniversite seviyesindeki eğitim, mesleki eğitim ve öğretim programları ile ortaöğretimdeki yeterlilikler ve üniversite eğitimi kapsamına girmeyen ortaöğretim sonrası yeterlilikler için kullanılmak üzere tasarlanmıştır. ISCED sınıflaması, konu-uzmanlığının bulunduğu genel eğitim programları ve yeterlilikleri için de kullanılabilir. Ancak, belirli bir alan veya alanlarda uzmanlaşmanın çok az olduğu veya hiç olmadığı geniş bir konu yelpazesini kapsayan genel eğitim programları ve yeterlilikler, tipik olarak 00 'genel programlar ve yeterlilikler' kategorisinde sinıflandırılacaktır.

ISCED (1976, 1997 ve 2011) versiyonlarında kullanılan yaklaşım aynıdır. İçerik bakımından yakın bir ilişkinin olması durumunda; konular, benzerliğe dayalı olarak, geniş, dar ve ayrıntılı sınıflama alanlarını oluşturmak için birlikte gruplandırılır.

Bir program veya yeterliliğin hangi eğitim ve öğretim alanında sınıflandırılacağını belirleyen husus, ana konudur. Konu, program süresince edinilen ve ilgili yeterlilik tarafından tanınan olgusal, uygulamalı ve teorik bilgidir. $\mathrm{Bu}$ bilgi, belirli problem türlerine veya spesifik amaçlara uygulanır. Bu problemler veya amaçlar, soyut (örneğin, felsefe), uygulamalı (örneğin, mühendislik) veya her ikisi birden yani hem soyut hem de uygulamalı (örneğin, mimarlık) olabilir. Pratik olması bakımından, bir programın veya yeterliliğin ana konusu, ayrıntılı alan itibariyle belirlenir. Ayrıntılı alanın tespitinde, öğrenme kredilerinin çoğunluğunun (örneğin \%50'den fazlası) veya açık bir şekilde baskın olan kısmının ilgili olduğu konu veya tasarlanmıș öğrenme zamanının çoğunun veya açık bir şekilde baskın olan kısmının harcandığı konu dikkate alınır. Eğer mevcutsa, öğrenme kredileri kullanılmalıdır. Aksi takdirde, önceden tasarlanmış öğrenme süresi esas alınarak yaklaşık bir değerlendirme yapılmalıdır. Öğrenme süresi, derslere ve seminerlere harcanan zamanın yanısıra laboratuvar veya bu derse özgü projelere harcanan zamanı da kapsar ve bunların dışında kalan harcanan özel çalışma süresi (öğrenciden öğrenciye değişiklik göstermesi ve ölçülmesinin zor olması sebebiyle) hariç tutulmuştur. Programlar ve yeterlilikler, ana konularını içeren ayrıntılı alanlar içinde sınıflandırılmıştır. 
Öğrenme kredilerinin veya tasarlanmıș öğrenme süresinin göreli paylarını belirlemek için yeterli bilgi bulunmadığında; program veya yeterlilik, başlığındaki ilk alana göre sınıflandırılmalıdır. Eğer, program veya yeterlilik, hiçbiri baskın bir paya sahip olmayan birkaç ayrıntılı alanı (ve hatta dar veya geniş alanları) kapsıyor ve bundan dolayı ana konu tanımlanamıyorsa; bu program veya yeterlilik disiplinlerarası kategorisinde sinıflandırılmalıdır.

Eğer iki program veya yeterliliğin öğrenim görülen ana konusu aynıysa veya yeterince benzerlik gösteriyorsa, bunlar aynı alana dâhil edilir. Sınıflamanın yapısı geliştirilirken, konuların benzerlik derecesini belirlemede öncelik sırasına göre aşağıdaki kriterler kullanılmış; eğitim ve öğretim alanlarının geniş, dar ve ayrıntılı alanlar itibariyle sınıflandırılması bu şekilde oluşturulmuştur:

a.Teorik bilgi içeriği (örneğin, kapsam içindeki fikirler ve kavramlar ve bunların olguları açıllamada ve sonuçları öngörmede kullanımı).

b.Öğrenmenin amacı (örneğin, kazanılan bilgi, beceri ve yetkinliklerin planlanmış kullanımı).

c. Kapsamdaki ögeler (örneğin, olgular, problemler veya incelenen varlıklar).

d.Yöntemler ve teknikler (örneğin, kazanılan bilgi ve becerileri öğrenme ve uygulama prosedürleri).

e.Araç ve gereçler (örneğin, bireylerin kullanmayı veya çalıştırmayı öğrendiği araçlar ve uygulamalar).

\subsection{Disiplinlerarası veya geniş programlar}

Disiplinlerarası programlar ve yeterliliklerde veya geniş programlar ve yeterliliklerde, tek bir ayrıntılı alan baskın olmayıp, birkaç ayrıntılı eğitim ve öğretim alanının bir arada bulunması sözkonusudur. Pek çok disiplinlerarası programlar ve yeterlilikler, birkaç dar alanı, hatta geniş alanları dahi kapsar. Bu sinıflamada, 'ana konu kurall', içinde disiplinlerarası eğitimin sınıflandırılacağı geniş alanı belirlemek için kullanılır. Yani, ana konu veya konular (geniş) alanı belirler. Ana konunun / konuların belirlenmesinde kullanılan kriter, daha önce de olduğu gibi, öğrencilerin tasarlanmıș öğrenme süresi veya öğrenme kredileri içindeki paydır. Disiplinlerarası programlar, ana geniş alan içinde yer alan dar ve ayrıntılı alan seviyelerinde sinıflandırılır. Böylece, baskın konusu olmayan bütün disiplinlerarası eğitim programları ayrı ayrı belirlenir ve en azından, bu program veya yeterliliğin ana geniş alanı bilinir. Örneğin, bir program eşit oranlarda (her biri üçte bir) teoloji (0221), tarih (0222) ve felsefeden (0223) olușuyorsa; 0288 olarak sınıflandırılır ('Sanat ve beșerî bilimlerin dâhil olduğu disiplinlerarası programlar ve yeterlilikler'). Eğer bir program, \%60 teoloji, \%20 tarih ve \%20 felsefe içeriyorsa, teoloji baskın konu olduğu için, bu program 0221 olarak siniflandırılır.

Disiplinlerarası programda birden fazla öncü geniş alan tespit edildiğinde; programın veya yeterliliğin adındaki ilk kelime esas alınarak geniş alan sınıflaması yapılır (Eğer başlıkta yer almıyorsa, müfredata veya ders içeriklerine bakılır). Ana konuyu belirlemek için yeterli bilgi yoksa, bir önceki cümlede açıklanan 'ilk listelenen' kuralı uygulanmalıdır.

İki veya daha çok ayrıntılı alanı kapsayan programlarda veya yeterliliklerde, eğer bir ayrıntılı alan tasarlanmış öğrenme süresinin veya öğrenme kredilerinin baskın oranını temsil ediyorsa; program veya yeterlilik sözkonusu ayrıntılı alanda sinıflandırılır. Dolayısıyla, öğrenme kredilerinin veya tasarlanmış öğrenme süresinin büyük kısmı tek bir ayrıntılı alana tahsis edilmişse; program / yeterlilik, bu ayrıntılı alan içerisinde sınıflandırılır ve disiplinlerarası bir program / yeterlilik olarak görülür. Örneğin, anadalı matematik, yandalı Fransizca olan bir program, baskin konu matematik olduğu için, 0541 'Matematik' olarak sınıflandırılmalıdır.

Belirli bir mesleki alana yönelik programlar ve yeterlilikler, eğer destekleyici konuları diğer alanlardan alıyorsa; bu programlar veya yeterlilikler, disiplinlerarası olarak kabul edilmez. Bu programlar ve yeterlilikler, sözkonusu mesleki alana göre sınıflandırılmalıdır. Örneğin, elektrik tesisatındaki bir programda, tasarlanmış mesleki konuya tahsis edilen süreden daha fazlası, diğer yardımcı konulara (dil, matematik, doğa bilimleri, vb.) ayrılmış olabilir. Ancak, bu program 0713 'Elektrik ve enerji' olarak sinıflandırılır ve disiplinlerarası bir program olarak kabul edilmez.

Öğrenim programlarının sinıflandırılmasında sadece bir kod atandığı sürece; 'ana konu kuralı', disiplinlerarası programları ve yeterlilikleri sınıflamak için tek makul çözümdür. Ancak, iki veya daha fazla kod (Toprak, Erdoğan ve Açıkgöz, 2013) atayan kullanıcılar, disiplinlerarası programları veya yeterlilikleri alanların bileşimlerine göre sinıflandırabilir.

'Daha ayrıntılı tanımlanmamış' ve 'başka yerde sınıflandırılmamış' kodlar, sınıflama yapısına dâhil edilmemiștir; ancak, bunlar tamamlayıcı kodlar olup, gerektiği gibi veya yeterli derecede açıklanmamıș ('daha ayrıntılı tanımlanmamış'); veya sınıflama yapısında ('başka yerde sınıflanmamış') açıkça kapsanmamış veriyi işlemede kullanılabilir.

'0,' '8' ve '9' kullanımlarını ayırt etmek zor olabilir. Bu durumda, Tablo 3.1 yardımcı olabilir.

Tablo 3.1. Tamamlayıcı kodlar

\begin{tabular}{|c|l|l|}
\hline Kod & \multicolumn{1}{|c|}{ İsim } & \multicolumn{1}{c|}{ Kullanım } \\
\hline 0 & $\begin{array}{l}\text { Daha ayrıntılı tanımlan- } \\
\text { mamış }\end{array}$ & $\begin{array}{l}\text { Sınıflamanın daha üst seviyesinde bili- } \\
\text { nen bilgiden başka bir bilgi yok }\end{array}$ \\
\hline 8 & $\begin{array}{l}\text { Disiplinlerarası programlar } \\
\text { ve yeterlilikler }\end{array}$ & $\begin{array}{l}\text { Baskın ayrıntılı alanın olmadığı prog- } \\
\text { ramlar ve yeterlilikler }\end{array}$ \\
\hline 9 & $\begin{array}{l}\text { Başka yerde sınıflandırı- } \\
\text { mamış }\end{array}$ & $\begin{array}{l}\text { Ayrıntılı alan bilinmektedir, ancak } \\
\text { sınıflamada verilmemiştir }\end{array}$ \\
\hline $\begin{array}{l}\text { Not: } \\
\text { kaskın bir ayrıntılı alanı olan programlar ve yeterlilikler (öğrenme } \\
\text { tanımlanin veya sürenin \%50'sinden fazlasını kapsayan), o baskın alanda }\end{array}$ \\
\hline
\end{tabular}

Çalışma alanının tamamen bilinmediği durumda, '9999' kodu atanır veya program eğer sadece dar veya geniş alan seviyeleri ile sinırlı ise sirasıly '999' veya '99' numaralı 
Tablo 3.2. ISCED Eğitim-Öğretim Alanları 2013 (ISCED-F)

\begin{tabular}{|c|c|c|}
\hline Geniş alan & Dar alan & Ayrıntılı alan \\
\hline 00 Genel programlar ve yeterlilikler & $\begin{array}{l}001 \text { Temel programlar ve yeterlilikler } \\
002 \text { Okuryazarlık ve rakamsal beceriler } \\
003 \text { Kişisel beceriler ve gelişim }\end{array}$ & $\begin{array}{l}0011 \text { Temel programlar ve yeterlilikler } \\
0021 \text { Okuryazarlık ve rakamsal beceriler } \\
0031 \text { Kişisel gelişim ve beceriler }\end{array}$ \\
\hline 01 Eğitim & 011 Eğitim & $\begin{array}{l}0111 \text { Eğitim bilimi } \\
0112 \text { Okul öncesi öğretmen yetiştirme } \\
0113 \text { Uzmanlık alanı olmayan öğretmen yetiştirme } \\
0114 \text { Uzmanlık alanı olan öğretmen yetiştirme }\end{array}$ \\
\hline \multirow[t]{3}{*}{02 Sanat ve beşerî bilimler } & 021 Sanat & $\begin{array}{l}0211 \text { Görsel-işitsel teknikler ve medya yapımı } \\
0212 \text { Moda, iç tasarım ve endüstriyel tasarım } \\
0213 \text { Güzel sanatlar } \\
\text { 0214 El sanatları } \\
\text { 0215 Müzik ve sahne sanatları }\end{array}$ \\
\hline & \multicolumn{2}{|l|}{$\begin{array}{l}\text { 022 Beşerî bilimler (diller hariç) } \\
\text { 0221 Din ve teoloji } \\
\text { 0222 Tarih ve arkeoloji } \\
\text { 0223 Felsefe ve etik }\end{array}$} \\
\hline & 023 Diller & $\begin{array}{l}0231 \text { Dil kazanımı } \\
0232 \text { Edebiyat ve dilbilim }\end{array}$ \\
\hline \multirow[t]{2}{*}{$\begin{array}{l}03 \text { Sosyal bilimler, gazetecilik ve } \\
\text { enformasyon }\end{array}$} & 031 Sosyal bilimler ve davranış bilimleri & $\begin{array}{l}0311 \text { Ekonomi } \\
0312 \text { Siyasal bilimler ve yurttaşlık } \\
0313 \text { Psikoloji } \\
0314 \text { Sosyoloji ve kültürel çalışmalar }\end{array}$ \\
\hline & 032 Gazetecilik ve enformasyon & $\begin{array}{l}0321 \text { Gazetecilik ve muhabirlik } \\
0322 \text { Kütüphane, enformasyon ve arşiv çalışmaları }\end{array}$ \\
\hline \multirow[t]{2}{*}{04 İşletme, yönetim ve hukuk } & 041 İşletme ve yönetim & $\begin{array}{l}0411 \text { Muhasebe ve vergileme } \\
0412 \text { Finans, bankacılık ve sigortacılık } \\
0413 \text { İşletme ve yönetim } \\
0414 \text { Pazarlama ve reklam } \\
0415 \text { Büro hizmetleri ve sekreterlik } \\
0416 \text { Toptan ve perakende Satış } \\
0417 \text { Çalışma becerileri }\end{array}$ \\
\hline & 042 Hukuk & 0421 Hukuk \\
\hline \multirow[t]{4}{*}{$\begin{array}{l}05 \text { Doğa bilimleri, matematik ve } \\
\text { istatistik }\end{array}$} & 051 Biyoloji ve ilişkili bilimler & $\begin{array}{l}0511 \text { Biyoloji } \\
0512 \text { Biyokimya }\end{array}$ \\
\hline & 052 Çevre & $\begin{array}{l}0521 \text { Çevre bilimleri } \\
0522 \text { Doğal çevre ve vahşi yaşam }\end{array}$ \\
\hline & 053 Fen bilimleri & $\begin{array}{l}0531 \text { Kimya } \\
0532 \text { Yer bilimleri } \\
0533 \text { Fizik }\end{array}$ \\
\hline & 054 Matematik ve istatistik & $\begin{array}{l}0541 \text { Matematik } \\
0542 \text { İstatistik }\end{array}$ \\
\hline 06 Bilgi ve İletişim Teknolojileri & 061 Bilgi ve İletişim Teknolojileri (ICT) & $\begin{array}{l}0611 \text { Bilgisayar kullanımı } \\
0612 \text { Veri tabanı ve ağ tasarımı ve yönetimi } \\
0613 \text { Yazılım ve uygulama geliştirme ve analizi }\end{array}$ \\
\hline \multirow[t]{3}{*}{07 Mühendislik, imalat ve inşaat } & 071 Mühendislik ve mühendislik işleri & $\begin{array}{l}0711 \text { Kimya mühendisliği ve süreçleri } \\
0712 \text { Çevre koruma teknolojisi } \\
0713 \text { Elektrik ve enerji } \\
0714 \text { Elektronik ve otomasyon } \\
0715 \text { Mekanik ve metal işleri } \\
0716 \text { Motorlu araçlar, gemi ve uçak }\end{array}$ \\
\hline & 072 İmalat ve işleme & $\begin{array}{l}0721 \text { Gıda işleme } \\
0722 \text { Malzeme (cam, kâğıt, plastik ve ağaç) } \\
0723 \text { Tekstil (elbise, ayakkabı ve deri) } \\
0724 \text { Madencilik ve maden çıkarma }\end{array}$ \\
\hline & 073 Mimarlık ve inşaat & $\begin{array}{l}0731 \text { Mimarlık ve şehir planlama } \\
0732 \text { Yapı ve inşaat mühendisliği }\end{array}$ \\
\hline \multirow[t]{4}{*}{$\begin{array}{l}08 \text { Ziraat, ormancılık, balıkçılık ve } \\
\text { veterinerlik }\end{array}$} & 081 Ziraat & $\begin{array}{l}0811 \text { Tarım ve hayvancılık } \\
0812 \text { Bahçecilik }\end{array}$ \\
\hline & 082 Ormancilık & 0821 Ormancilık \\
\hline & 083 Balıkçılık & 0831 Balıkçılık \\
\hline & 084 Veterinerlik & 0841 Veterinerlik \\
\hline
\end{tabular}




\begin{tabular}{|c|c|c|}
\hline Geniş alan & Dar alan & Ayrıntılı alan \\
\hline \multirow[t]{2}{*}{09 Sağlık ve refah } & 091 Sağlık & $\begin{array}{l}0911 \text { Dişçilik } \\
0912 \text { Tıp } \\
0913 \text { Ebelik ve hemşirelik } \\
0914 \text { Tıbbi teşhis ve tedavi teknolojisi } \\
0915 \text { Terapi ve rehabilitasyon } \\
0916 \text { Eczacılık } \\
0917 \text { Geleneksel ve tamamlayıcı tıp ve terapi }\end{array}$ \\
\hline & 092 Refah & $\begin{array}{l}0921 \text { Yaşlı ve engelli yetişkin bakımı } \\
0922 \text { Çocuk bakımı ve gençlik hizmetleri } \\
0923 \text { Sosyal hizmet ve rehberlik }\end{array}$ \\
\hline \multirow[t]{4}{*}{10 Hizmetler } & 101 Kişisel hizmetler & $\begin{array}{l}1011 \text { Ev hizmetleri } \\
1012 \text { Saç ve güzellik hizmetleri } \\
1013 \text { Otel, restoran ve yiyecek } \\
1014 \text { Spor } \\
1015 \text { Seyahat, turizm ve eğlence }\end{array}$ \\
\hline & 102 Hijyen ve iş sağlığı hizmetleri & $\begin{array}{l}1021 \text { Toplum sağlığı } \\
1022 \text { İş sağlığı ve güvenliği }\end{array}$ \\
\hline & 103 Güvenlik hizmetleri & $\begin{array}{l}1031 \text { Askerlik ve savunma } \\
1032 \text { Kişilerin ve malların korunması }\end{array}$ \\
\hline & 104 Ulaşım hizmetleri & 1041 Ulaşım hizmetleri \\
\hline \multicolumn{3}{|c|}{$\begin{array}{l}\text { Yukarıdaki tablodaki ayrıntılı alanlara ek olarak; “ } 0 \text { ”, “8” ve “9” kullanılabilir: } \\
\text { '8', disiplinlerarası veya geniş programları ve yeterlilikleri, tasarlanmış sürenin çoğunun harcandığı geniş alan itibariyle sınıflandırırken, dar ve ayrıntıl } \\
\text { alan seviyesinde kullanılır (örneğin, } 0288 \text { 'Beşerî bilimler ve sanatı kapsayan disiplinlerarası programlar ve yeterlilikler'). Alan hakkında, sınıflama } \\
\text { hiyerarşisinin bir üst seviyesinde (örneğin, geniş alan düzeyinde veya dar alan düzeyinde) verilen açıklamadan başka bir bilgi mevcut değilse '0' } \\
\text { kullanılır. } \\
\text { '9', programlar ve yeterlilikler sınıflandırılırken, eğer listelenmiş ayrıntılı alanlarda yer almıyorlarsa veya herhangi birine de uymuyorlarsa, ayrıntılı } \\
\text { alan için kullanılır. } \\
\text { '9999',' '999' veya '99' özellikle alanın bilinmediği veri derleme çalışmalarında kullanılabilir. }\end{array}$} \\
\hline
\end{tabular}

Kaynak: UNESCO, https://unesdoc.unesco.org/ark:/48223/pf0000228085

kodlar kullanılır.

\subsection{ISCED geniş, dar ve ayrıntılı alanları}

ISCED, uluslararası karşılaştırmalarda kullanılmak üzere, genelden özele doğru üç kırılımda alan sınıflandırması yapmaktadır: Geniş alan, dar alan, ayrıntılı alan. Genelden özele doğru gittikçe gruptaki alan sayısı artmaktadır (Tablo 3.2).

\subsection{ISCED sınıflamasında doğrudan kod ve dolaylı kod kullanımı}

ISCED sınıflamasında birden fazla geniş alanı, birden fazla dar alanı veya birden fazla ayrıntılı alanı ilgilendiren programların kodlanmasında izlenen yol disiplinlerarası kod verilmesidir. Ancak bu disiplinlerarası kodun sağladığı bilgi değeri oldukça sınırlıdır. Sonuçta, ISCED sınıflamasında her bir eğitim programına sadece bir kod verilmekte, eğer disiplinlerarası ise yine disiplinlerarası olarak tek kod verilmektedir.

ISCED sınıflamasının cevap vermediği ve Türkiye'nin ulusal düzeyde ihtiyaç duyduğu bir konu, ikinci, üçüncü ve hatta dördüncü alanla ilişkilendirmedir. Örneğin, Veterinerlikte Biyoloji ve Genetik tezli yüksek lisans programına, biyoloji, tıbbi genetik ve veterinerlik kodları birlikte verilememektedir. Bu sorunu aşmanın yolu, ulusal düzeydeki kullanımda, birden fazla kod vermedir. İlk kod ISCED'de öngörüldüğü kurallara göre verilir ve doğrudan kod olarak kabul edilirken, öncelik sırasına göre diğer iki kod dolaylı kod olarak verilir. Bu çalışmada, Türk yükseköğrenim programları sınıflandırılırken, doğrudan kod ve dolaylı kod kullanımı yoluna gidilmemiş, YÖK'ün belirlediği tek kod kullanımı benimsenmiștir. Aşağıdaki tabloda, halihazırda Türk yükseköğrenim sisteminde bulunan bazı programlar için doğrudan kod ve dolaylı kod kullanımına ilişkin öneriler bulunmaktadır (Tablo 3.3).

\section{SONUÇ}

Türk yükseköğrenim sistemi iki parametre çerçevesinde değerlendirilebilir. Birincisi, sistemin kurgu, işleyiş ve referans aldığı düzenleme ve yapılar iken, ikinci parametre mevcut yükseköğrenim programlarının çeşit ve sayısı, bunlara kayıtlı öğrenci sayısı ve öğretim elemanı bakımindan potansiyelidir.

Türk yükseköğrenim sistemi, organizasyonel ve işlevsel tasarım, çıktı ve süreç bazlı kalite güvencesi, önceki öğrenmelerin tanınması, farklı öğrenme türleri arasında kredi ve kazanım transfer imkânı ve hesap verebilirlik bakımından gelişmiş ülkelerin sistemleriyle uyumlu bir yapıdadır. Önlisanstan, doktoraya kadar diplomaya dayalı yükseköğrenim programlarından mezun olanların alan bilgisi ve dil bilgisi bakımından performansı, düzenleyici çerçevenin öngördüğü düzeyde olmamakla birlikte, referans çerçevelerin mevcut olması değerlendirme bakımından önemli bir mihenk taşı oluşturmaktadır. Dolayısıyla, Avrupa Birliğine üyelik sürecinde, Türk yükseköğrenim sisteminin organizasyon ve performans değerlendirmesi bakımından Avrupa yükseköğrenim alanını referans alması, Türkiye bakımından yasal bir yükümlülük olduğu kadar aynı zamanda önemli bir kaldıraçtır.

Türkiye'de eğitim, meslek ve unvan ile ekonomik faaliyetler arasında insan kaynağı planlamasının MEB, YÖK, eski Devlet Planlama Teşkilatı, Çalışma Bakanlığı gibi ulusal düzeydeki düzenleyici otoriteler tarafından ve iş- 
Tablo 3.3. ISCED sınıflamasında doğrudan kod ve dolaylı kod kullanımı

\begin{tabular}{|c|c|c|c|c|}
\hline Düzey & Program adı & $\begin{array}{c}\text { Birinci kod } \\
\text { (doğrudan kod) }\end{array}$ & $\begin{array}{l}\text { Ikinci kod } \\
\text { (dolaylı kod) }\end{array}$ & $\begin{array}{l}\text { Üçüncü kod } \\
\text { (dolaylı kod) }\end{array}$ \\
\hline Önlisans & Acil Yardım Yönetimi & $\begin{array}{l}1032 \text { Kişilerin ve malların } \\
\text { korunması }\end{array}$ & 091 Sağlık & 0413 İşletme ve yönetim \\
\hline Önlisans & Et ve Ürünleri Teknolojisi & 0721 Gıda işleme & $\begin{array}{l}0719 \text { Mühendislik ve mühendislik } \\
\text { işleri- başka yerde sınıflanmamış }\end{array}$ & \\
\hline Önlisans & Pancar Yetiştiriciliği ve Şeker Teknolojisi & 0811 Zirai ve hayvansal üretim & $\begin{array}{l}0719 \text { Mühendislik ve mühendislik } \\
\text { işleri- başka yerde sınıflanmamış }\end{array}$ & \\
\hline Önlisans & Peyzaj Uygulama ve Süs Bitkileri & $\begin{array}{l}0731 \text { Mimarlık ve şehir } \\
\text { planlama }\end{array}$ & 0812 Bahçecilik & \\
\hline Lisans & İslam Ekonomisi ve Finans & 0311 Ekonomi & 0412 Finans, bankacılık ve sigortacilık & 0221 Din ve teoloji \\
\hline Lisans & Lojistik Yönetimi & 0413 İşletme ve yönetim & 1041 Ulaşım hizmetleri & \\
\hline Lisans & Organik Tarım İşletmeciliği & 0413 Işletme ve yönetim & 0811 Zirai ve hayvansal üretim & \\
\hline Lisans & Sağlık İdaresi & 0413 İşletme ve yönetim & $\begin{array}{l}0919 \text { Sağlık-başka yerde sınıflan- } \\
\text { mamış }\end{array}$ & \\
\hline Lisans & Sanat ve Kültür Yönetimi & 0213 Güzel sanatlar & 0314 Sosyoloji ve kültürel çalışmalar & 0413 Işsletme ve yönetim \\
\hline Lisans & Turizm İşletmeciliği ve Otelcilik & 0413 İşletme ve yönetim & 1013 Otel, restoran ve ikram & \\
\hline Lisans & Uçak Elektrik-Elektronik & $\begin{array}{l}0716 \text { Motorlu araçlar, gemi } \\
\text { ve uçak }\end{array}$ & 0713 Elektrik ve enerji & $\begin{array}{l}0714 \text { Elektronik ve } \\
\text { otomasyon }\end{array}$ \\
\hline Yüksek Lisans & Hayvansal Ürünler Hijyen ve Teknolojisi & 0721 Gıda işleme & 0811 Zirai ve hayvansal üretim & 1021 Toplum sağlığı \\
\hline Yüksek Lisans & $\begin{array}{l}\text { Lojistik Sistemler Yönetimi ve Mühen- } \\
\text { disliği }\end{array}$ & $\begin{array}{l}0719 \text { Mühendislik ve mü- } \\
\text { hendislik işleri- başka yerde } \\
\text { sınıflanmamış }\end{array}$ & 0413 İşletme ve yönetim & 1041 Ulaşım hizmetleri \\
\hline Yüksek Lisans & Mühendislik ve Teknoloji Yönetimi & $\begin{array}{l}0718 \text { Disiplinlerarası } \\
\text { mühendislik ve mühendislik } \\
\text { işleri }\end{array}$ & $\begin{array}{l}061 \text { Bilgi ve İletişim Teknolojileri } \\
\text { (ICT) }\end{array}$ & 0413 İşletme ve yönetim \\
\hline $\begin{array}{l}\text { Yüksek Lisans } \\
\text { (disiplinlerarası, } \\
\text { tezli) }\end{array}$ & Adli Bilişim Mühendisliği & $\begin{array}{l}0688 \text { Bilgi ve Illetişim Tekno- } \\
\text { lojileriyle ilgili disiplinlerarası } \\
\text { programlar ve yeterlilikler }\end{array}$ & 0512 Biyokimya & $\begin{array}{l}071 \text { Mühendislik ve } \\
\text { mühendislik işleri }\end{array}$ \\
\hline $\begin{array}{l}\text { Yüksek Lisans } \\
\text { (tezli) }\end{array}$ & Deniz Teknolojisi Mühendisliği & $\begin{array}{l}0716 \text { Motorlu araçlar, gemi } \\
\text { ve uçak }\end{array}$ & 1041 Ulaşım hizmetleri & $\begin{array}{l}0522 \text { Doğal çevre ve vah- } \\
\text { şi yaşam }\end{array}$ \\
\hline $\begin{array}{l}\text { Yüksek Lisans } \\
\text { (tezsiz) }\end{array}$ & Bilim-Teknoloji ve Toplum & $\begin{array}{l}0314 \text { Sosyoloji ve kültürel } \\
\text { çalışmalar }\end{array}$ & 022 Beşerî bilimler & $\begin{array}{l}06 \text { Bilgi ve İletişim Tek- } \\
\text { nolojileri }\end{array}$ \\
\hline Doktora & Biyokompozit Mühendisliği & $\begin{array}{l}0711 \text { Kimya mühendisliği ve } \\
\text { süreçleri }\end{array}$ & $\begin{array}{l}0722 \text { Malzeme (cam, kâğıt, plastik } \\
\text { ve ağaç) }\end{array}$ & 0512 Biyokimya \\
\hline Doktora & $\begin{array}{l}\text { Çevre Bilimleri Mühendisliği ve } \\
\text { Yönetimi }\end{array}$ & 0712 Çevre koruma teknolojisi & 0521 Çevre bilimleri & 0413 İşletme ve yönetim \\
\hline Doktora & Eczacılık İşletmeciliği & 0916 Eczacilık & 0413 İşletme ve yönetim & \\
\hline Doktora & Egzersiz Fizyolojisi & 0915 Terapi ve rehabilitasyon & 1014 Spor & \\
\hline Doktora & Eskiçağ Dilleri ve Kültürleri & 0232 Edebiyat ve dilbilim & 0314 Sosyoloji ve kültürel çalışmalar & \\
\hline Doktora & Kelam ve İslam Felsefesi & 0221 Din ve teoloji & 0223 Felsefe ve etik & \\
\hline Doktora & Sualtı Arkeolojisi (Dr) & 0222 Tarih ve arkeoloji & 0712 Çevre koruma teknolojisi & \\
\hline Doktora & Tarım Ekonomisi & 0311 Ekonomi & 081 Ziraat & \\
\hline Doktora & Türk İslam Sanatları Tarihi & 0213 Güzel sanatlar & 0221 Din ve teoloji & 0222 Tarih ve arkeoloji \\
\hline
\end{tabular}

Kaynak: YÖK İstatistik Veri Tabanı, https://istatistik.yok.gov.tr/

birliği içinde yapıldığı kabul edilmektedir. Ne var ki, karar alma, planlama ve uygulama için geçen süre ile ekonomik sektörlerde ve teknolojide meydana gelen değişmeler arasında, zaman uyumsuzluğundan kaynaklanan önemli gecikmeler olmaktadır. Cumhurbaşkanlığı hükumet sisteminin, kurumlar arasındaki uyumsuzluk ve koordinasyon açığını kapatmadaki performansını değerlendirme için yeterli bir süre geçmediği için, Türkiye'de mevcut yapı ve işleyiş performansı hakkında değerlendirme zaman kısıtı nedeniyle şu an için yapılamamaktadır.

$\mathrm{Bu}$ çalışmada, uluslararası standart eğitim sınıflaması (ISCED) çerçevesinde Türk yükseköğrenim programları çeşit, sayı, öğrenci sayısı ve öğretim kadrosu itibariyle bir sınıflamaya tabi tutulmuştur. Bu çerçevede, Türk yükseköğrenim sistemindeki diploma programları için aşağıdaki tespitler yapılabilir: YÖK'ün yükseköğrenim prog- ramlarını tabi tuttuğu sınıflamada 12 temel alan tespiti yapılmışken, ISCED'de 10 temel alan ve bir de genel alan sözkonusudur. YÖK sınıflamasında, programların bağlı olduğu akademik birimler (fakülte, yüksek okul, enstitü) ile geleneksel alan tasarımı (iktisadi ve idari bilimler, fen, edebiyat, ziraat programları gibi) 12 temel alanın belirlenmesinde etkili olmuştur. Yine mühendislik, mimarlık, doktorluk, eczacılık ve benzeri yapılandırılmış alanlardaki ulusal mevzuat da temel alan tasarımında etkili olmuştur. ISCED sinıflamasında ise bilimsel yakınlık veya benzemezlikler esas alınarak alan sınıflaması üç farklı kırılımda (geniş alan, dar alan ve ayrıntılı alan) yapılmaktadır.

Türk yükseköğrenim sisteminde 5.540 çeşit program bulunmakta, bunların \%20'si pasif olup, kayıtlı öğrenci bulunmamaktadır. Toplam program sayısı 41.145 olup, program çeşidi başına düşen program sayısı ortalama 


\section{8,1'dir.}

Yükseköğrenimde kayıtlı öğrenci sayısı 7,7 milyon olup bunun \%50,1'i açık öğretime kayıtlıdır. Örgün öğretime (birinci öğretim ve ikinci öğretim) kayıtlı öğrenci oranı \%48, 8 iken, uzaktan öğretim öğrenci oranı \%1,1'dir. Örgün öğretimde öğretim elemanı başına düşen öğrenci sayısı ortalama $85^{\prime}$ tir.

Yükseköğrenime kayıtlı öğrencilerin (açı öğretim hariç) \%84'ü devlet üniversitelerinde, \%16'sı vakıf üniversitelerinde (vakıf MYO dahil) eğitim görmektedir. Eğitim düzeylerine göre toplam öğrenci sayısı (açı öğretim hariç) içinde ön lisansın payı $\% 25,5$, lisansın payı $\% 61,8$, yüksek lisansın payı $\% 10,2$ ve doktoranın payı $\% 2,5$ düzeyindedir.

Yükseköğrenim sistemi içinde açık öğretimin payının \%50'yi aşması ve uzaktan eğitimle birlikte daha da yükselmesi üzerinde durulması gereken bir husustur. Mevcut örgün eğitim programlarından mezun olanların, kamu kurumları sınavlarına girdiklerinde gösterdikleri düşük performans, taşrada atıl örgün eğitim kapasiteleri ile yeni teknolojik imkânların gerektirdiği eğitim ortamları dikkate alındığında, Türk yükseköğrenim sisteminin ciddi bir değerlendirmeye ihtiyacı olduğu söylenebilir.

Türkiye'de üniversite eğitiminde mesleki ve akademik yönelim program çeşidi itibariyle tanımlanmamakla birlikte, yükseköğretim kanununda önlisans ve tezsiz yüksek lisans programlarının mesleki, diğer programların ise akademik olduğu yönünde açıklamalar bulunmaktadır. Ne var ki, lisans, tezli yüksek lisans ve doktora programları bakımından akademik ve mesleki yönelimin tanımlı olması ve program anahtar öğrenme kazanımlarının bu doğrultuda yeniden belirlenmesi ve güncellenmesi gerekmektedir (Özer, 2019 ve 2018; Yağan ve Çubukçu 2019; Toprak ve Erdoğan 2013). Avrupa Yükseköğrenim Alanı ve Avrupa Araştırma Alanındaki güncellemelerin Türk yükseköğrenim sistemine de içerilmesi önemli bir referans olacaktır.

Türk yükseköğreniminde 5.540 program çeşidinde önlisans programlarının payı $\% 11$, lisans programlarının payı $\% 13$, yüksek lisans programlarının payı $\% 53$ ve doktora programlarının payı \%23 civarındadır. 41.145 program sayısı içinde, önlisans programları \%29, lisans programları \%27, yüksek lisans programları \%31 ve doktora programları \%13 civarında paya sahiptir.

Türkiye, uluslararası öğrenci çekme bakımından oldukça düşük bir performansa sahiptir. Mevcut uluslararası öğrencilerin neredeyse tamamı tam burslu veya kısmi burslu statüsünde olup, ayrıca yaşam maliyetleri için aylık sabit ödemeler de yapılmaktadır. 2017-18 akademik yılında Türkiye'deki yabancı uyruklu üniversite öğrenci sayısı 125 bin civarındadır. Bunların \%31'i Ortadoğu, \%30’u Türk dünyası ve \%13'ü Afrika ülkeleri uyrukludur. Batı Avrupa ve Balkanlar dikkate alındığında, uluslararası öğrencilerin Türkiye ile etnik ve dini bağlantılarının oldukça yüksek olduğu söylenebilir.
Türkiye'deki üniversiteler yurtiçi ve yurtdıșı üniversitelerle ikili anlaşmaları dışında başlıca üç tür değişim programı ile öğrenci değișimi yapmaktadır. Farabi, Mevlâna ve Erasmus. Farabi yurtiçindeki yükseköğretim kurumları arasında değişim programı iken, Mevlâna Türk devlet üniversiteleri ile yabancı ülkelerdeki üniversiteler arasında değişim programı ve Erasmus ise Avrupa yükseköğrenim alanında geçerli olan değişim programıdır. Mevlâna programından yararlanan gelen ve giden öğrenci sayısı birlikte toplam öğrenci sayısı yılllk bazda 400-500 arasinda değişmektedir. Erasmus programından yararlanan öğrenci sayısı ise gelen ve giden birlikte olarak yıllık bazda toplam 9.000 civarındadır.

Haziran 2019 itibariyle Türkiye'de 167 bin civarında akademik personel bulunmaktadır. Akademik personel içinde profesörler \%16, doçentler \%9, doktoralılar \%24, öğretim görevlileri \%22 ve araştırma görevlileri \%29 oranındadır. Akademik personelin \%85'i devlet üniversitelerinde kadrolu iken, yardımcı doçentlerin (doktor öğretim üyesi) \%20'si vakıf üniversitelerinde, araştırma görevlilerinin ise \%93'ü devlet üniversitelerinde kadrolu olarak çalışmaktadır. Dolayısıyla, devlet üniversitelerinin akademik kapasite yaratmada önemli bir işlev gördüğü ve yükseköğrenim sistemine akademik personel yetiştirmede esas sorumluluğu aldığı söylenebilir. Türk yükseköğrenimindeki akademik personelin \%49'u doktora derecesine sahipken, \%51'i öğretim görevlisi ve araștırma görevlisi kadrosundadır. Üniversite sistemindeki öğretim kadronun \%22'sinin doktora derecesine sahip olmamaS1 ve araştırma görevlisi oranının \%29 oranında olması, Türk yükseköğreniminin gelişme çağında olduğuna işaret etmektedir.

Öğrencisi olan aktif programlarda program başına düşen öğretim elemanı sayısı ortalama 3,8 iken, ortalama öğretim üyesi sayısı 1,9'dur. Öğretim elemanı başına düşen öğrenci sayısı ortalama 23 iken, öğretim üyesi başına düşen öğrenci sayısı ortalama 47'dir. Araştırma üniversitesi, kalkınma odaklı üniversite, eğitim üniversitesi ve uygulama üniversitesi gibi kavramların Türk üniversite sisteminin potansiyeli ve kapasitesi bakımından dikkate alınarak, sistemdeki yükseköğrenim kurumlarının yeni bir tasnifinin yapılması ve yeterlilikler, önceki öğrenmenin tanınması ile kalite güvence sistemlerinin bu doğrultuda farklılaştırllarak geliştirilmesi gerekmektedir.

Türk yükseköğrenim sistemi, gelişmiș ülkelerin sistemleriyle karşılaştırıldığında kapalı bir sistem olduğu söylenebilir. Gerek uluslararası öğrenci gerekse uluslararası öğretim elemanı bakımından bu kapalı sistem özelliği oldukça barizdir.

Yükseköğrenimde yeni gelișen alanlara hitap eden ancak kendi başına bir program olarak tasarlanacak kadar özgünlükte olmadığı halde, benzer içerikli ancak farklı isimli programlar mevcuttur. Büyük ölçüde sadece isimde farklılaşmış programlar, ISCED, ISCO ve ISIC sınıflamaları birlikte dikkate alınarak mümkün olduğunca alan 
gruplamasına gidilerek program çeșitliliği azaltılabilir ve böylece yeterlilikler çerçevesi, kalite güvencesi ve akreditasyonun daha etkin ve hızlı uygulanma imkânı ortaya çıkabilir.

Türkiye'de öğrenim görmeyi tercih eden uluslararası öğrenci portföyü göz önüne alındığında üniversitelerde uluslararasılaşmanın çeșitli șekillerde desteklenmesi gerektiği gözlenmekte olup, gerekli altyapı ve teșviklerle bu konunun önceliklendirilmesi Türkiye'nin görece kapalı eğitim sisteminden gelişime (uluslararası bilgi akıșına) daha açık bir eğitim sistemine geçişinde kolaylık sağlayacaktır. Ayrıca ileri teknoloji seviyesindeki ülkeler ile eğitim değişim ağları kurulması desteklenerek teknolojik ilerlemenin eğitim yoluyla hızlıca içselleştirilmesi sağlanabilir. Yabancı öğretim elemanlarının en azından Türk vatandaşı öğretim elemanlarıyla aynı koşullarda çalışma izni imkânına sahip olması, yabancı dilde eğitim bakımından hayati bir gerekliliktir. Aksi halde, yabancı dilde eğitim verme imkânı, Türk vatandaşı öğretim kadrosu bakımından kısa ve orta vadede pek mümkün görünmemektedir.

Üniversite-sanayi işbirliğinde organizasyonel ve yasal düzenlemeler önemli ölçüde tamamlanmıș durumdadır. Ancak, bu yapıların işletilmesinde ve teşvik mekanizmalarının etkinliğinde sorunlar yașanmaktadır. Üniversiteler ile özel sektör arasında AR-GE faaliyetlerinin artırılması için ilave enstrümanlara ihtiyaç vardır. Üniversitelerde kurulan teknoloji transfer ofisleri/tekno parklar artırılarak bu merkezlerde yapılan araştırma ve geliştirme faaliyetleri teşvik edilebilir.

Yeterlilikler çerçevesi, kalite güvencesi, akreditasyon, önceki öğrenmenin tanınması ve sosyal boyut konusunda işleyişte önemli bir yetersizlik ve etkinsizlik sözkonusudur. Bu yönde, tedbir uygulamasıyla sonuçlanacak mekanizmaların kurulması ve enstrümanların etkinleștirilmesi gerekmektedir.

Yükseköğrenim sisteminin hem bilgi ve yeni teknoloji üretimi hem de mevcut bilgi ve teknolojileri kullanabilme kapasitesini artırmaya yönelik gözden geçirilmesinin faydalı olacağı değerlendirilmektedir.

\section{REFERANSLAR}

Alsharari, Nizar Mohammad. (2018). Internationalization of the higher education system: an interpretive analysis. International Journal of Educational Management, 32(3), 359-381.

Cedefop (2018). The changing nature and role of vocational education and training in Europe. Vol. 3: the responsiveness of European VET systems to external change (1995-2015). Cedefop research paper, No 67. https://www.cedefop.europa. eu/files/5567_en.pdf.

Chen, Derek H.C. ve Dahlman Carl J. (2004). Knowlwdge and development: A cross-section approach. World Bank Research Working Paper 3336. August 2004.

Chhokar, Kiran Banga. (2010). Higher education and curriculum innovation for sustainable development in India. In- ternational Journal of Sustainability in Higher Education. 11(2), 141-152.

Ergin, Gözde ve Türk, Fahri. (2010). Türkiye'de öğrenim gören Orta Asyalı öğrenciler. Sosyal ve Beşerî Bilimler Dergisi. 2(1), 35-41.

Gülmez, Deniz ve Yavuz, Mustafa. (2019). Türkiye, Amerika Birleşik Devletleri ve Birleşik Krallık yükseköğretim kurumlarının amaç ve yapı boyutları bakımından değerlendirilmesi. Yükseköğretim ve Bilim Dergisi. 9(1), 144-155.

Günay, Durmuş ve Günay. Aslı. (2011). 1933'den günümüze Türk yükseköğretiminde niceliksel gelişmeler, Yükseköğretim ve Bilim Dergisi. 1(1), 1-22.

Günay, Durmuş ve Özer, Mahmut. (2014). Türkiye'de meslek yüksekokulları, mevcut durum, sorunlar ve çözüm önerileri. Ankara: Yükseköğretim Kurulu Y.

Günay, Durmuş ve Özer, Mahmut. (2016). Türkiye'de meslek yüksekokullarının 2000'li yıllardaki gelişimi ve mevcut zorluklar. Yükseköğretim ve Bilim Dergisi, 6(1), 1-12.

Gür, Bekir S., Çelik, Zafer ve Yurdakul, Serkan. (2018). Yükseköğretime bakış 2018: İzleme ve değerlendirme raporu. Ankara: Eğitim-Bir-Sen Stratejik Araştırmalar Merkezi.

Güzel, Bekir. (2014). Mevlâna değişim programının lisans öğrencilerinin sosyokültürel gelişimine olan katkısının değerlendirilmesi. Uluslararası Sosyal Araştırmalar Dergisi. 7(32), 486-494.

Huisman, Jeroen, Luijten-Lub, Anneke ve van der Wende, Marijk. (2015). Explaining domestic responses to European policies: The impact of the Erasmus programme on national higher education policies. International Perspectives on Higher Education Research. 3, 5-27.

ILO. (1988). International Standard Classification of Occupations, ISCO-88. https://www.lo.org/public/english/bureau/ stat/isco/isco08/

ILO. (2008). International Standard Classification of Occupations, ISCO-08. https://www.lo.org/public/english/bureau/ stat/isco/isco08/index.htm

Johnson, Mark S. (2015). Historical legacies of Soviet higher education and the transformation of higher education systems in post-Soviet Russia and Eurasia. The Worldwide Transformation of Higher Education. 159-176.

Karabayev, Baki ve Tutkun, Ömer F. (2001). Türk Cumhuriyetlerinden gelen öğrencilerin Türkiye Cumhuriyeti vatandaşlarına karşı taşıdıkları kalıp yargılar. Bilig. 18, 1-26.

Kavak, Yüksel ve Baskan, Gülsün Atanur. (2001). Türkiye'nin Türk Cumhuriyetleri, Türk ve akraba topluluklarına yönelik eğitim politika ve uygulamaları, Hacettepe Üniversitesi Eğitim Fakültesi Dergisi. 20, 92-103.

Li, Jun ve Lin, Jing. (2015). China's move to mass higher education: An analysis of policy making from a rational framework. The Worldwide Transformation of Higher Education. 9, 269-295

Lombardi, Rosa ve diğ. (2017). Emerging trends in entrepreneurial universities within Mediterranean regions: An international comparison. EuroMed Journal of Business. 12(2), 130-145.

Markowitsch, Jörg ve Plaimauer, Claudia. (2009). Descriptors for competence: towards an international standard classification for skills and competences. Journal of European 
Industrial Training. 33(8/9), 817-837.

Mongkolhutthi, Preechaya. (2019). Inequality and imbalance of professional development opportunities: The case of a higher educational institution in Southeast Asia. Journal of Applied Research in Higher Education. https://doi. org/10.1108/JARHE-01-2018-0010

MYK. (2016). Turkish Referencing Report, Ankara.

Ngok, Kinglun. (2008). Massification, bureaucratization and questing for "world-class" status: Higher education in China since the mid-1990s. International Journal of Educational Management. 22(6), 547-564.

Niu, Dongjie, Jiang, Dahe ve Li, Fengting. (2010). Higher education for sustainable development in China. International Journal of Sustainability in Higher Education. 11(2), 153-162.

Özer, Mahmut. (2018). 2023 eğitim vizyonu ve mesleki ve teknik eğitimde yeni hedefler, Yükseköğretim ve Bilim Dergisi. 8(3), 425-435.

Özer, Mahmut. (2019). Mesleki ve teknik eğitimde sorunların arka planı ve Türkiye'nin 2023 eğitim vizyonunda çözüme yönelik yol haritası. Yükseköğretim ve Bilim Dergisi. 9(1), $1-11$.

Özkan, İsa. (2007). Bağımsızlıklarının 15. Yılında Türk Cumhuriyetlerinde Eğitim ve Sosyal Değişme. Türk Cumhuriyetlerinde Eğitim ve Sosyal Değişme, TOBB Y. 91-135.

Phusavat, Kongkiti ve diğ. (2011). Developing a university classification model from performance indicators. Performance Measurement and Metrics. 12(3), 183-213.

Saginova, Olga ve Belyansky, Vladimir. (2008). Facilitating innovations in higher education in transition economies. International Journal of Educational Management. 22(4), 341-351.

Siemienska, Renata ve Walczak, Dominika. (2012). Polish higher education: from state toward market, from elite to mass education. Research, Practice and Praxis. 7, 197-224.

Soysal Yılmaz ve diğ. (2019). Türkiye yükseköğretimindeki kavramsal, olgusal, tematik ve yöntembilimsel tercihler. Yükseköğretim ve Bilim Dergisi. 9(1), 17-36.

Spöttl, Georg. (2013). Permeability between VET and higher education - a way of human resource development. European Journal of Training and Development. 37(5), 454-471.

Stonkiene, Marija, Matkeviciene, Renata ve Vaiginiene, Erika. (2016). Evaluation of the national higher education system's competitiveness: Theoretical model. Competitiveness Review. 26(2), 116-131.

Toprak, Metin, Kolat, Deniz ve Şengül, Mehmet. (2018). ISCED Eğitim ve Öğretim Alanları 2013, (ISCED-F 2013) Kılavuzu. Yükseköğretim Dergisi. 8(1), 113-123.

Toprak, Metin ve Erdoğan, Armağan. (2013). Lisansüstü eğitimde Avrupa yaklaşımı. VI. Ulusal Lisansüstü Eğitim Sempozyumu, Bildiriler Kitabı, Sakarya Üniv. Y., Yayın No 95, 10-36.

Toprak, Metin, Erdoğan, Armağan ve Açıkgöz, Ömer. (2013). Field qualifications: A framework suggestion. The New Educational Review. 31(1), 153-164.

UNESCO. (2015). International Standard Classification of Education: Fields of Education and Training 2013 (ISCED-F 2013) - Detailed Field Descriptions. http://uis.unesco.org/ sites/default/files/documents/international-standard-classification-of-education-fields-of-education-and-trai- ning-2013-detailed-field-descriptions-2015-en.pdf

UNSD. (2008). International Standard Industrial Classification of all Economic Activities (ISIC). https://unstats.un.org/ unsd/iiss/International-Standard-Industrial-Classification-of-all-Economic-Activities-ISIC.ashx

van Vught, Frans A., van der Wende, Marijk C. ve Westerheijden, Don F. (2018), Globalisation and differentiation in higher education systems. Theory and Method in Higher Education Research. 85-101.

Wu, Yen-Chun Jim ve Shen, Ju-Peng. (2016). Higher education for sustainable development: a systematic review. International Journal of Sustainability in Higher Education. 17(5), 633-651.

Yağan, Saadet Aylin, \& Çubukçu Zühal. (2019). Türkiye ve İngiltere doktora programlarının karşılaştırılması. Yükseköğretim ve Bilim Dergisi. 9(1), 134-143.

YÖK. (2018). Yükseköğretim Kurulu 2018 Yılı Yükseköğretim Kurumları Sınavı Yerleştirme Sonuçları Raporu. Ankara.

YÖK. (2019). Yükseköğretim Kurulu 2019 Yılı Yükseköğretim Kurumları Sınavı Yerleştirme Sonuçları Raporu. Ankara. https://www.basarisiralamalari.com/yok-yks-yerlestirme-sonuc-raporu-yayimladi/ https://www.yok.gov.tr/HaberBelgeleri/Haber\%20\%C4\%B0\%C3\%A7erisindeki\%20Belgeler/ Dosyalar/2019/yks_2019_sonuc_raporu.pdf 